\title{
IMPACT OF CLIMATIC VARIATIONS ON THE FLOWERING PHENOLOGY OF PLANT SPECIES IN JHELUM DISTRICT, PUNJAB, PAKISTAN
}

\author{
MAJEED, M. ${ }^{1}-$ BHATTI, K. H. ${ }^{1}-$ AMJAD, M. S..$^{2 *}$ \\ ${ }^{I}$ Department of Botany, University of Gujrat, Hafiz Hayat Campus, Gujrat, Punjab, Pakistan \\ ${ }^{2}$ Department of Botany, Women University of Azad Jammu and Kashmir, 12500 Bagh, Pakistan \\ *Corresponding author \\ e-mail: malikshoaib1165@yahoo.com; phone: +92-345-381-2987
}

(Received $14^{\text {th }}$ Feb 2021; accepted $14^{\text {th }}$ May 2021)

\begin{abstract}
District Jhelum is located in the extremely diverse province of Punjab, Pakistan, and flowering event in plants is always influenced by the environment. This study was conducted during 2018 to 2020 to investigate the climatic effects on flowering cycle of plants. The main focus of the study was to find out the particular association between flowering phenology of plants and climatic variables. Month-wise phenological response of plants was recorded during frequent field visits at multiple representative microhabitats. The response data is saved as binary data matrix, and mean monthly climatic data is obtained through remote sensing, and analysed by using multivariate analyses like canonical correspondence analysis, hierarchical classification and pseudocanonical correlation. CCA and Hierarchical classification were applied to assess the importance climatic variations towards the flowering phenological response and potential groups respectively. A total of 404 plant species of 223 genera belonging to 75 plant families were examined. Majority of plant species were found in flowering during the month of March (174 spp.) followed by April (159 spp.) and August (158 spp.), similarly, Summer was the leading season (208 spp.) followed by Monsoon (203 spp.), Spring (181 spp.) and Autumn (157 spp.). CCA results depicted that total variations in the flowering phenology response data were 3.45084, and about $45.6 \%$ were explained by the explanatory climatic variables. Wind speed, mean monthly maximum temperature and soil moisture were detected as most influential drivers of flowering phenology in the study area. The current study will be useful for researchers as a major source of knowledge for the conservation of valuable species. Such type of attempts will be supportive to explore the phenological response of plants in various habitats such as forest, hilly, riverine, desert and range lands flora in their future projects.

Keywords: phenological response, hierarchical classification, canonical correspondence analysis
\end{abstract}

\section{Introduction}

The word "phenology" stands for the life history of plants (Vashistha et al., 2009). To record phenological response at local and regional scale some modeling tools and remote sensing play significant role (Neil and $\mathrm{Wu}, 2006$ ). Phenology of plants is recorded through observation during ecological explorations to estimate month wise or season wise data including the last stage of appearance (Meier et al., 2007; Menzel et al., 2006). During documentation of ground truth data, various climatic variables were recorded for comparative data analysis (Badeck et al., 2004). In an ecosystem clear effects of climatic variables on phenological response were determined (Kolb et al., 2007). Climatic and phenological relations were documented by many research studies (Petry et al., 2016). Phenology and climatic conditions are linked to multiple scales (Bertin, 2008), environmental variables can affect the functional aspects of plants in any ecosystem (Parmesan, 2006; Calinger et al., 2013) resulting in close relationships among plant pollinators and plant species (Forrest, 2015; Kharouba and Vellend, 2015), and also among migratory birds and plants (Both et al., 2006). In life of plants, some unpredicted 
circumstances can affect the flowering event such as extreme temperature, day length and humidity, and studies documenting the influence of current climate on phenological events become extremely important because researchers already predicted a remarkable potential change in future climate. The presence or absence of biotic factors such as, grazers and insect pollinators and abiotic factors such as temperature, day length, and rainfall which influence the pattern of phenology (Thomson, 2010).

Various research studies resulted that temperature had significant effect on Phenology of plant species. But it was noted that temperature and phenological effect was not uniform in the World. The reason depicted that there was fluctuation in temperatures from different regions. Each species showed particular effect of temperature on phenology. So, the effect of temperature varied from species to species. In different regions of the World, with altitudinal variations, temperature played a basic role in different phenological response (Luo et al., 2007) (Holway and Ward, 1965; Shen et al., 2015; Luo et al., 2007) (Mooney and Billings, 1960). At different stages of phenology, the plants showed variable response at various temperature (Vashistha et al., 2009). International Panel on Climate Change, stated that a global rise of $0.74{ }^{\circ} \mathrm{C}$ in surface temperature results in environmental changes including less snow cover, rise in glacier melting, rise in sea level and variations in environmental temperature, rainfall and wind speed (Change, 2007).

In various regions of the World, climatic variations affected phenological responses greatly. The major climatic factors which influence the phenological pattern among various species are temperature, soil moisture, precipitation and rainfall (Chambers et al., 2013; Liu et al., 2016a, b; Inouye, 2008; Wolkovich and Cleland, 2011; Sun et al., 2015; Shen et al., 2016; Buyantuyev and Wu, 2012; Piao et al., 2019; Ma et al., 2013; Yu et al., 2003; Zhang et al., 2018; Visser et al., 2010; Richardson et al., 2013; Badeck et al., 2004; Zalamea and González, 2008). Globally, various seasons also play an important role in the phenology of plant species (Piao et al., 2019; Wolkovich and Cleland, 2011; Mittermeier et al., 2019; Gordo and Sanz, 2005; Morisette et al., 2009; Chambers et al., 2013; Yang et al., 2017).

Many studies resulted that temperature directly had direct influence on the phenological response among various plants species (Piao et al., 2019; Cleland et al., 2007; Cornelius et al., 2013; Prevéy et al., 2017; Crabbe et al., 2016; Shen et al., 2011; Keenan et al., 2020). Whereas, seasonal environmental variations showed a clear association to flowering period of plants. While phonological period, during life cycle of plants, represent prominent association with temperature. Moreover, in some cases, humidity, soil moisture, soil composition and soil texture influence the plant phenology (Cleverly et al., 2016; Francioli et al., 2018; Nandintsetseg and Shinoda, 2011; Peña-Barragán et al., 2011; Bodin and Morlat, 2006). Soil showed a major effect on the life cycle of plants. Many studies from different regions of the World, revealed the influence of soil factors on phenological pattern of plant species (Pausas and Austin, 2001; Okusanya et al., 2016; Anderson et al., 2012; Tadey, 2020; Tooke and Battey, 2010; Staehlin and Fant, 2015; Hulme, 2011; Cleland, 2007; Godoy et al., 2009; Neil et al., 2010; Lesica and Kittelson, 2010; Khanduri et al., 2008; Chen et al., 2020; Wolkovich and Cleland, 2014; McEwan et al., 2011; Matthews and Mazer, 2016).

The effect of climate and phenological response among large number of plants species was investigated in different geographical regions (Menzel et al., 2006; Parmesan, 2006; Parmesan and Yohe, 2003). Phenological response during spring season were recorded from many decades (Chambers et al., 2013; Schwartz et al., 2013; Ge et al., 2015), while phenological stages were not reported exactly (Menzel et al., 2006; Gill et al., 2015). From terrestrial ecosystems, flowering patterns of plant which played a significant role as 
biological factor are influenced by climate variations (Rosenzweig et al., 2007; Khan et al., 2018; Wang et al., 2018). It is resulted that species with progress in phenology with the rise in temperature will have better chances of survival. Such types of species represented maximum number of flowers, biomass production and vegetation cover. On the other hand, species which do not respond to climate variation faced hazard with short growth period as compared to active competitors (Cleland et al., 2012). As, such types of plant species not responding to temperature changes are facing a rapid decline in their abundance during the previous 150 years (Willis et al., 2008). Many ecologists reported the impact of topography, anthropogenic and climatic changes and possible causes upon various plant species (Khan et al., 2019a, b).

Ecologists should focus on durable and long lasting programming of existing natural resources to assess biodiversity of rich flora from unexplored regions by using multivariate analyses as comprising ordination techniques and hierarchical classification (Khan et al., 2019a, b). Moreover, the district Jhelum, Punjab, Pakistan was still unexplored, mainly relating to plant species indicating phenology and its patterns. As a result, the first ever comprehensive research was conducted to explore the unexplained aims which were

a. to explore the flowering response of angiosperms during the year in different seasons and monthly base

b. to discover the effect of climatic factors on phenological response of the plant species.

The current attempt will convey effective ecological knowledge to the researchers, range land managers, foresters, botanists and ecologists in future studies but also provide many valuable plant species grouping with the phonological response.

\section{Materials and methods}

\section{Study area}

District Jhelum from Pakistan is located towards North of the river Jhelum and bounded by district Rawalpindi in the North, Sargodha and Gujrat districts lies in the South, Azad Kashmir is situated East, and district Chakwal is located West (Mushtaq et al., 2011; Shah et al., 2013; Majeed et al., 2021). Total population of the district Jhelum is 1.223 million, $71 \%$ population lives in rural areas while the remaining $29 \%$ population lives in urban area (Altaf et al., 2018). The climatic condition showed that the district is semi-arid, warm subtropical region and is categorized by warm summer and severe winters. Jhelum is a semi-mountainous range, mean annual rainfall is $880 \mathrm{~mm}$ per annum while annually temperature in average is $23.6^{\circ} \mathrm{C}$. Jhelum river is compromise up to 247,102 acres of main land of plains on the other hand 41,207 acres is covered by hills (Figs. 1 and 2). The second largest salt mine of the world (Khewra) is in Jhelum which covers an area of 2268 acres (Shah et al., 2013; Hamidov et al., 2016). People of district Jhelum have their diverse mode of life span, culture, traditions, beliefs and have been using indigenous plants for various purposes (Iqbal et al., 2011). The ethnic groups of the area showed a strong linkage with wild plants of cultural and medicinal significance (Majeed et al., 2020).

\section{Floristic and phenological data collection}

The research area was floristically explored 2018-2020 (3 years) to record plant species. The main focus was to record the phenological response to climatic changes with reference 
to season and monthly basis. The collected specimens of plant species were tagged with voucher number, pressed, fully dried and finally mounted on the International standard sized sheets of herbarium, following the identification by applying Flora of Pakistan (URL: http://www.efloras.org/) and cross matched with floristic literature (Qureshi et al., 2011; Ali and Nasir, 1989; Ali and Qaiser, 1995). Afterward the initial possible identification of specimens, presently established binomials of each plant species and the family names were copied from the plant list ver. 1.1 (URL: http://www.theplantlist.org/) (TPL, 2013), as proposed by (Khan et al., 2016), to evade any taxonomic mistakes and misperception linked to ordering and placement. Further information comprising local names (Cain and Castro, 1960), were also documented. Frequent field visits were conducted to note phenology and to collect the plant samples from study sites. To record phenological responses of plant species, 171 altitudinal transects (Grids $5 \times 5 \mathrm{~km}^{2}$ ) containing 513 samples and 1539 subplots were studied by applying stratified random vegetation sampling method. Sub-plots (quadrates) size was $10 \times 10 \mathrm{~m}$ for tree layer, $5 \times 5 \mathrm{~m}$ for shrub layer and $1 \times 1 \mathrm{~m}$ for herbaceous layer (herbs and grasses). The completely prepared voucher specimens were placed in the herbarium of the Department of Botany, University of Gujrat, Punjab, Pakistan for future reference and record. Phenological response of each reported plant species was found out by using the given equation:

$$
\text { SFR }(\%)=\frac{\text { Species recored during floweing in a month }}{\text { Total plant species docomented in study area }} \times 100
$$

where: SFR is monthly-based species flowering phenological response. Likewise, the monthly-based response is used to determine the seasonal based flowering response for each plant species, and this classification include winter season (November to February), spring (March to April), summer (May to August), monsoon (July to September), and autumn season (September to October). While family importance value (FIV) was calculated with given equation:

$$
\text { FIV }(\%)=\frac{\text { Species belong to plant family }}{\text { total plant species reported in study area }} \times 100
$$

\section{Climate data collection}

In the study area, the climate conditions vary both in temporal and spatial scales. The climate data including environmental precipitation, maximum and minimum temperature, humidity, soil moisture, wind speed, and downward short and long wave radiations (2010$2019=10$ years) of the study area (Jhelum) was developed from the United States National Centers for Environmental Prediction (US-NCEP), Climate Forecast System Reanalysis (CFSR) by applying climate engine, (https://app.climateengine.org/). The temperature data source was CFSv2 $19200 \mathrm{~m}$ (1/5-deg) daily reanalysis dataset (NOAA) (Table 2).

\section{Statistical analyses}

The reported data of phenological response was put in Microsoft excel spreadsheet (plant species vs month-seasons), binary data matrix. Phenology of plant species was recorded monthly. Climatic and phenological data was calculated and linked to remote sensing data created with R statistical package (Ilyas et al., 2013), to produce pairwise correlation, distribution and scatterplots (Khan et al., 2015, 2018). Hierarchical clustering tree for months and seasons (Distance; Correlation, Linkage; Ward) was established and the 
package was named as "pvclust" with R statistical package (Team, 2014). CCA was applied by using Canoco software (Ter Braak and Šmilauer, 2012), to find out the impact of climatic factors to show variations in the data for binary response (Khan et al., 2018).

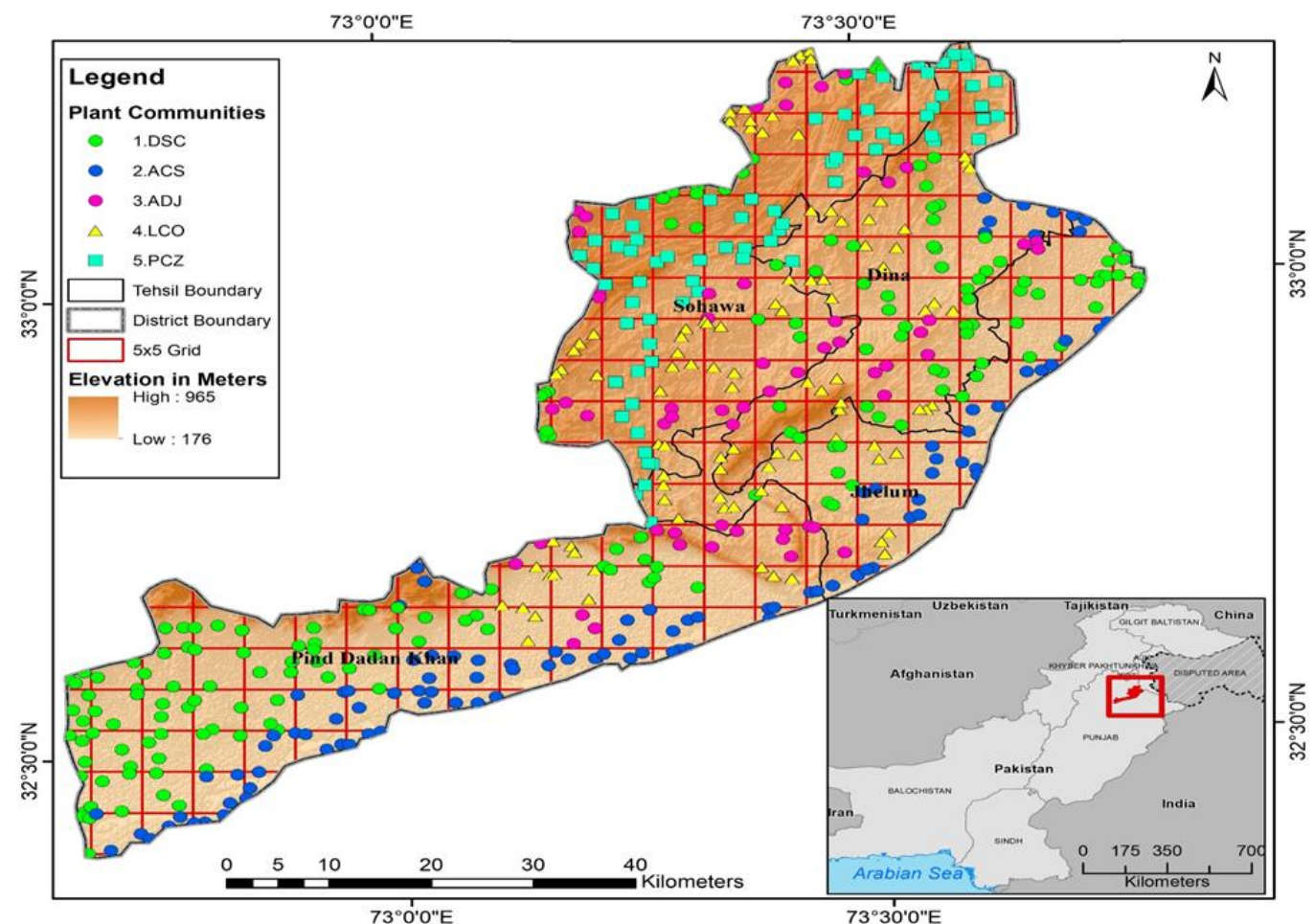

Figure 1. Map of the study area representing the points of quadrates at different elevations in the district of Jhelum
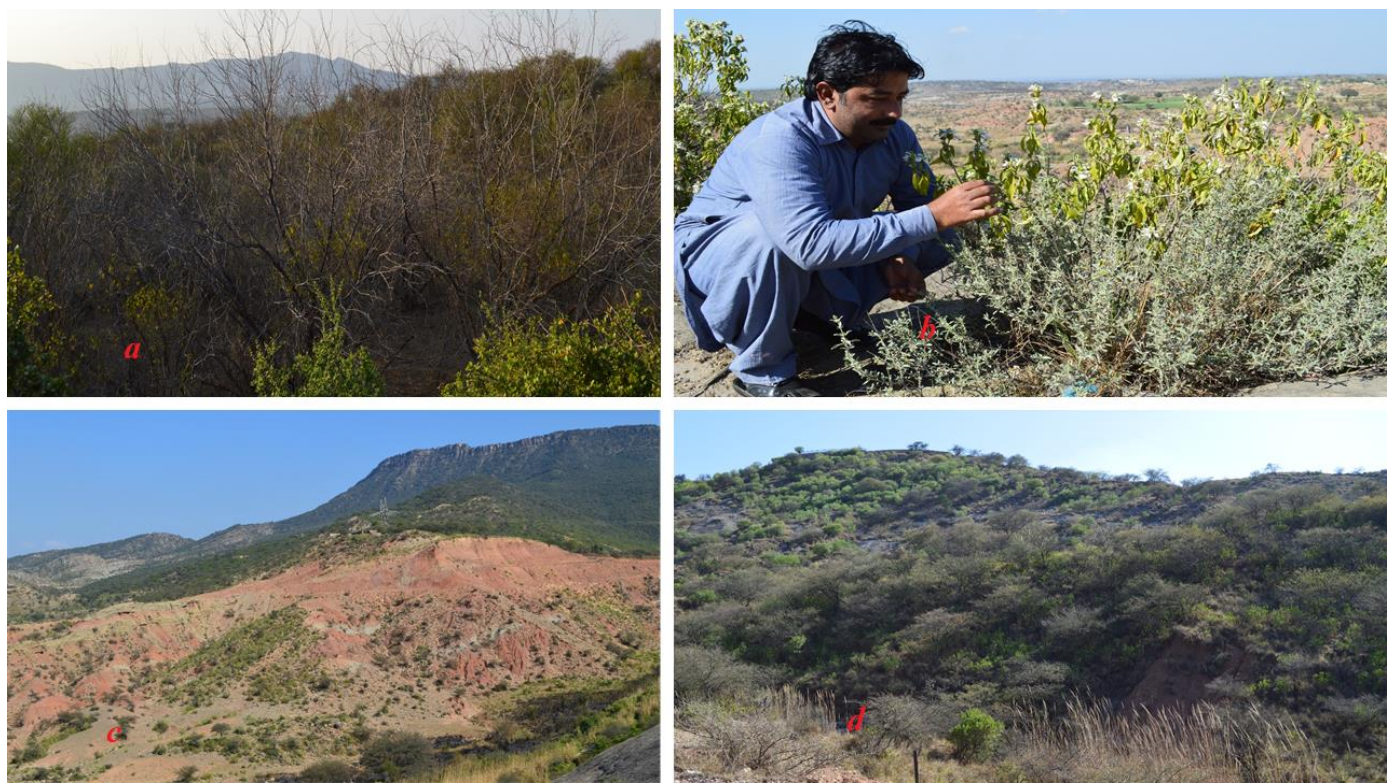

Figure. 2. Landscape representing richness of flora of the study area (a) forest (b) first author identifying plant species $(c)$ view of salt range $(d)$ view of hilly vegetation 


\section{Results}

The record of phenology period of each plant species is a fundamental and important element of such explorations. Reproductive phenological response is permanently interrelated to unique set of climatic variables of any area, thus, assessment of essential climatic factors are needed to lean any potential future climate variation influences.

\section{Floristic classification}

A total of 404 plant species were explored including vascular plants belonging to Angiosperms (402 species (99.5\%)), Gymnosperms (1 species $(0.45 \%)$ ) and nonvascular Pteridophytes (1 species (1.33\%)) including 223 genera and 75 families. Angiosperms were further classified as dicot including 328 species (81.19\%), 177 $(79.37 \%)$ genera and 63 families $(84 \%)$ while monocot comprised of 74 species (18.32\%), $44(19.73 \%)$ genera and 10 families (13.33\%) (Table 1). The leading plant family was Poaceae (59 spp., 14.6\%), followed by Leguminosae (57 spp., 14.11\%), Amaranthaceae (27 spp., 6.68\%) and Solanaceae (19 spp., 4.7\%) (Fig. 3), while the leading genus was Euphorbia (10 spp., 2.48\%), followed by Brassica (7 spp., 1.783\%), Heliotropium, Acacia, Solanum (6 spp., 1.49\% each.) (Fig. 4).

Table 1. Summary of floristic composition in Jhelum district, Punjab, Pakistan

\begin{tabular}{c|c|c|c}
\hline Phyto-Taxa & Families & Genera & Species \\
\hline Pteridophytes & $1(1.33 \%)$ & $1(0.45 \%)$ & $1(0.25 \%)$ \\
Gymnosperms & $1(1.33 \%)$ & $1(0.45 \%)$ & $1(0.25 \%)$ \\
Angiosperms & $73(97.33 \%)$ & $221(99.1 \%)$ & $402(99.5 \%)$ \\
Monocots & $10(13.33 \%)$ & $44(19.73 \%)$ & $74(18.32 \%)$ \\
Dicots & $63(84 \%)$ & $177(79.37 \%)$ & $328(81.19 \%)$ \\
Total & $75(100 \%)$ & $223(100 \%)$ & $404(100 \%)$ \\
\hline
\end{tabular}

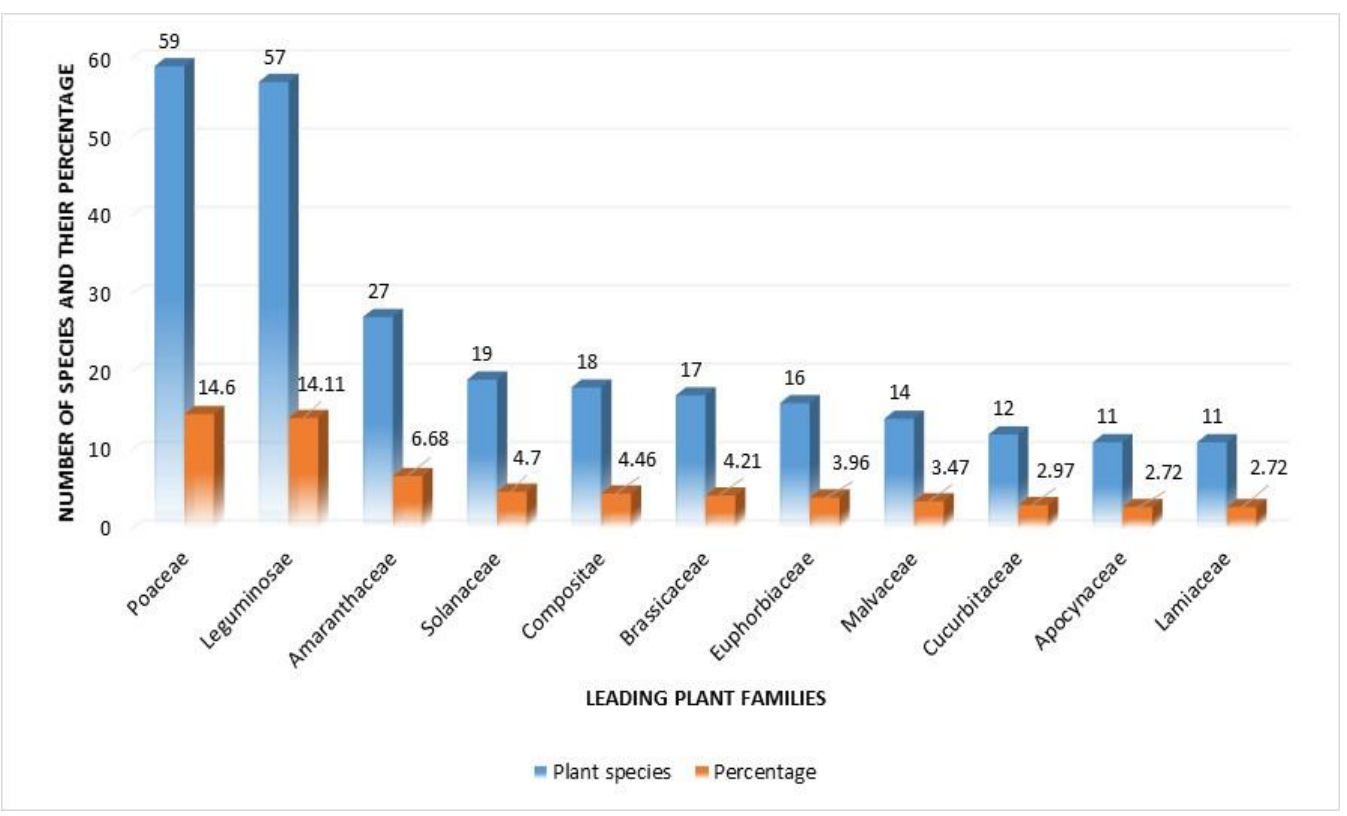

Figure 3. Graph depicting the leading plant families in the study area 


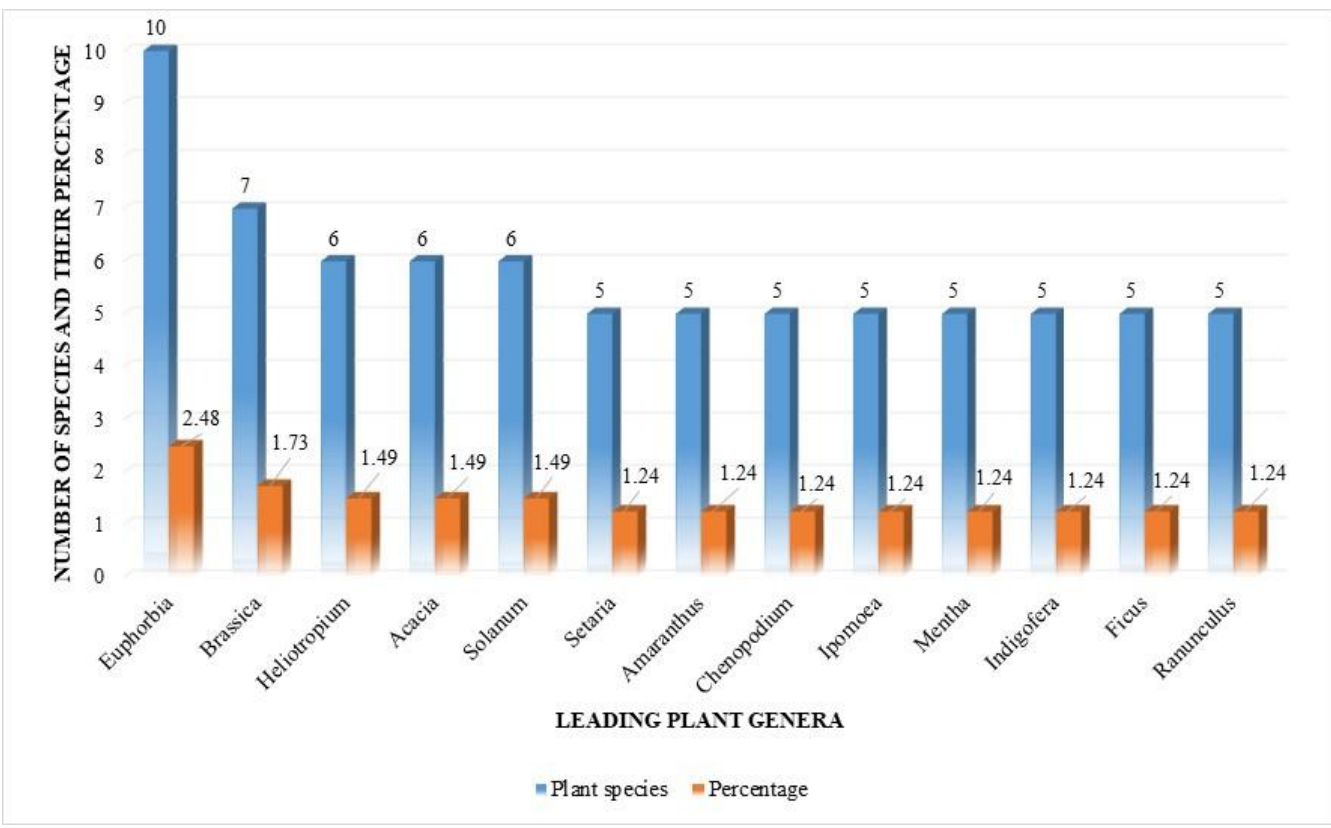

Figure 4. Graph depicting the leading plant genera in the study area

With respect to the diverse microhabitats, grassland showed the maximum number of 283 species (70.05\% of overall flora), followed by 281 road side species $(69.55 \%), 228$ forest species (55.44\%) and 223 arable land species (55.2\%), rest of micro-habitat resulted waste places with 216 species (53.47\%), hilly slope with 209 species $(51.73 \%)$, shady places with 184 species (45.54\%), graveyard with 174 species (43.07), wet land with 129 (31.93\%), dry land with 122 species (30.2\%), scrubland and home garden, both with 110 species (27.23\%), sandy places with 92 species $(22.77 \%)$ and mountain summits with 34 species $(8.2 \%)$. An overall habit-wise arrangement of the documented plant species showed four groups. Maximum number of herbs involved 246 species $(60.89 \%)$, followed by grasses with 59 species (14.6\%), shrubs with 50 species (12.38\%) and trees with 49 species (12.13\%) (Fig. 5).

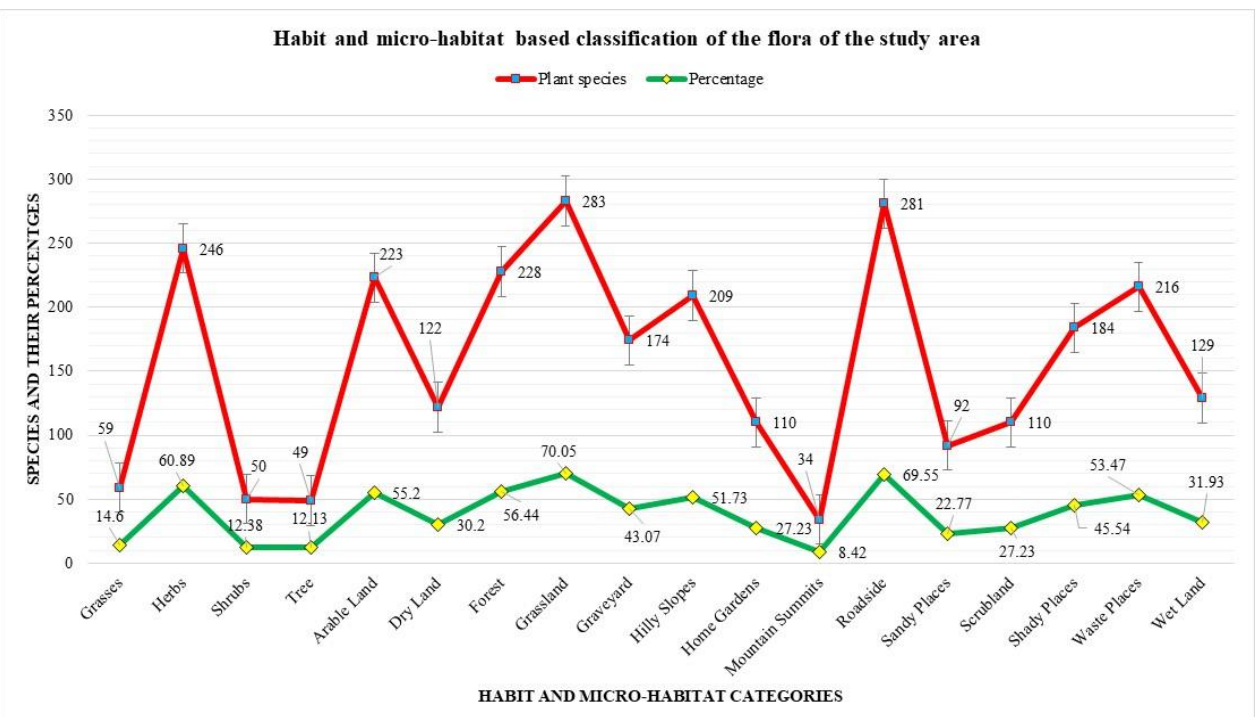

Figure 5. A graph depicting the results of grouping of vascular plant species into different habitat and micro-habitat categories 


\section{Flowering phenology and classification}

The reproductive phenological response recorded and showed that maximum flowering stage of plant species was during months of March, April and August (174 spp., 43.07\%, 159 spp., 39.36\% and 158 spp., 39.11\%). The minimum phonological response was noted in the month of January and December (5 spp., 1.24\%) and November (7 ssp., 1.73\%) (Fig. 6).

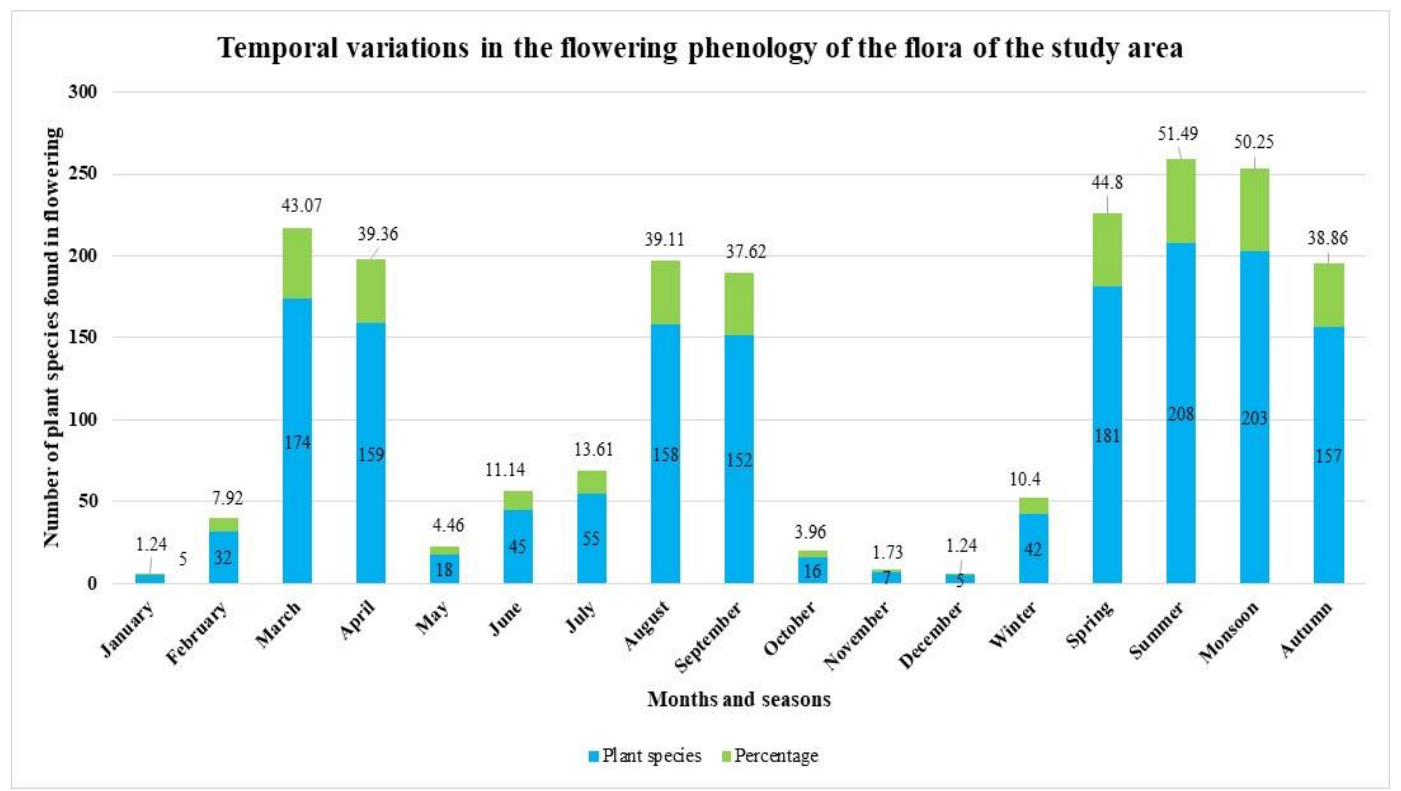

Figure 6. Graphical representation of temporal variations in the flowering phenology of the vascular plant species

The reproductive phenology response resulted that the majority of the plant species go through their reproductive phase during March, April, August and September months in a year, while, November to January is not a favored time to arrive into effective reproductive phonological phase due to ecological fluctuations. As far as the beginning time for species phenological response is depicted, most of the plant species started the flowering period in the months of February (32 spp., 7.92\%), May (18 spp., 4.45\%), June (45 spp., 11.14\%) and July (55 spp., 13.61\%). While, decline in flowering response with reduced number of plant species occurred in the month of October in 16 spp., 3.96\%) (Fig. 7).

Leading reproductive phenological response results were shown in the summer by 208 species (51.49\%) followed by Monsoon with 203 species (50.25\%), during Spring with 181 species (44.8\%) and Autumn with 157 species (38.86\%). The least phenological response was recorded during Winter in 42 species (10.4\%) (Fig. 8).

\section{Ordination analysis}

With reference to ordination analysis, detrended correspondence analysis (DCA), a unimodal unconstrained model (where as climatic factors were applied for supplementary variables) was designated to pursue the gradient length in the binary compositional phenological response data. The results of presented analysis represented that the gradient length in the response data was above $3 \mathrm{SD}$ (standard deviation of species turnover) for 
the first two DCA axes. Moreover, the response data was binary (1/0), by concluding data on the basis of the given two observations, a constrained uni-modal ordination model such as CCA was used to find out the type variables in the phenological response data described by the recorded predictions, and sort of importance order.

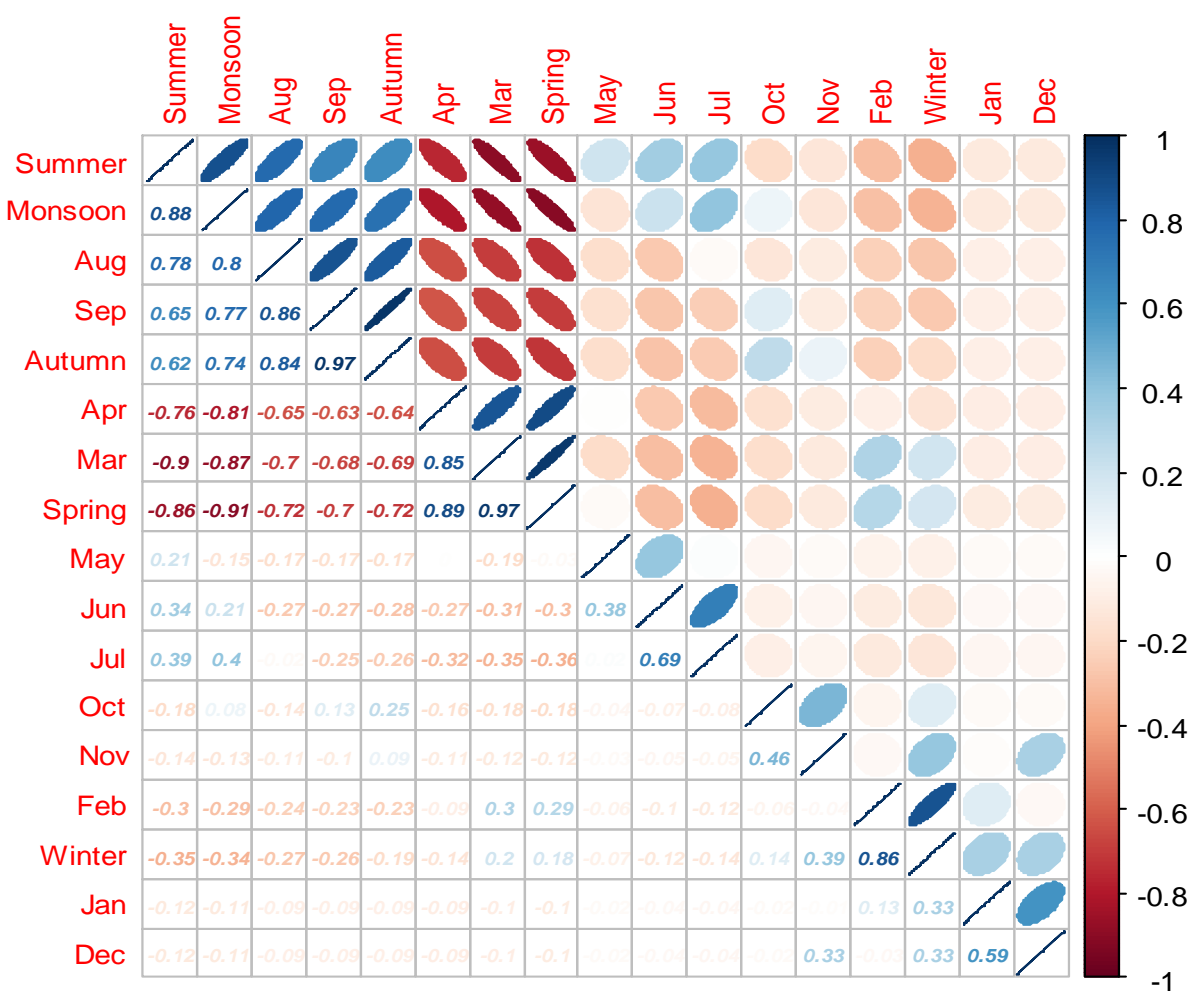

Figure 7. Correlation plot of months and seasons based on their flowering phenology response

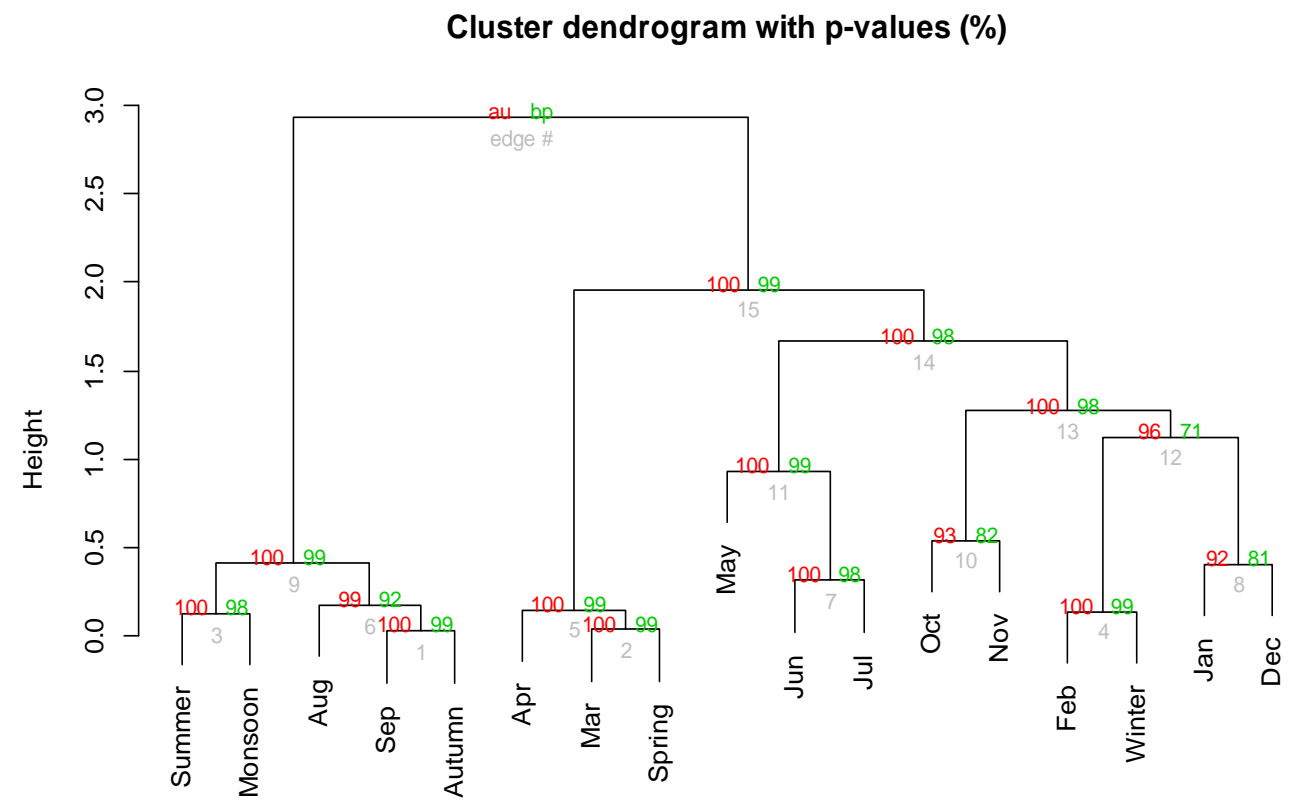

Figure 8. Hierarchical clustering tree of Months and seasons (Distance: Correlation, Linkage: Ward) with $A U / B P \%$ values based on their flowering phenology response 
The results of Pearson's correlation and its significance showed that overall plant species found in flowering phenological phase in different months is strongly correlated $(r>0.8)$ with mean monthly values of five different climatic variables. These include mean soil moisture $(\mathrm{r}=0.65)$, followed by precipitation variable that was found moderately positively correlated $(\mathrm{r}=0.62)$, mean specific humidity $(\mathrm{r}=0.60)$, long wave radiations $(r=0.52)$, shortwave radiations $(r=0.49)$, mean minimum temperature $(\mathrm{r}=0.46)$, mean maximum temperature $(\mathrm{r}=0.40)$, and similarly, a strong negative correlation was observed with wind speed $(\mathrm{r}=0.36)$ in the study area (Figs. 9 and 10).

Pairwise Pearson's correlation of climate and flowering phenology

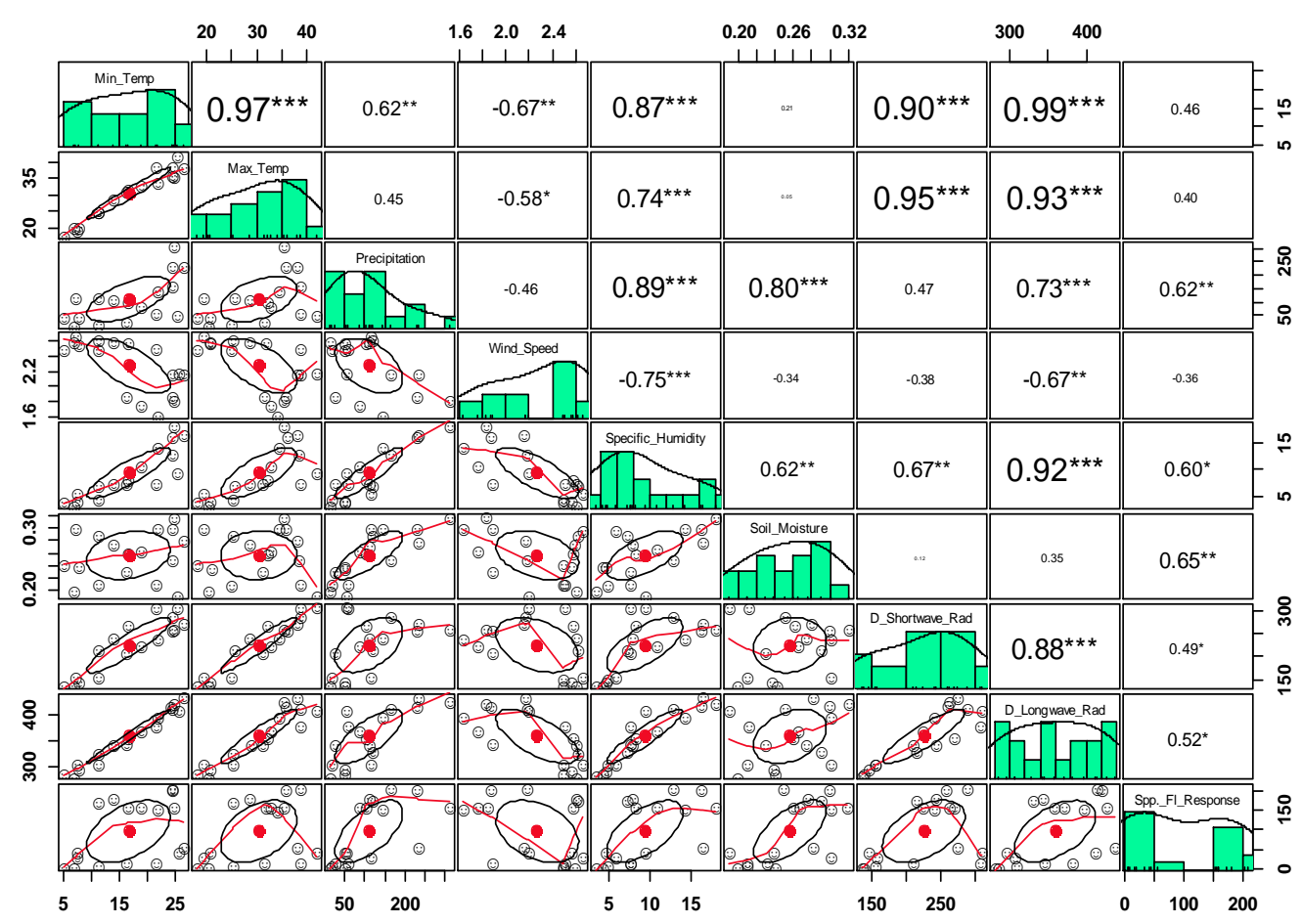

Figure 9. Graph representing correlation significance. (The distribution of each variable is shown on the diagonal. On the bottom of the diagonal the bivariate scatter plots with a fitted line, and ellipses are presented, while on the top of the diagonal the value of the correlation plus the significance level as stars. Each significance level is linked to a symbol: $p$-values $(0$, $0.001,0.01,0.05,0.1,1)<=>$ symbols (“***”, “**”, “*”, “.”, ““)

The results showed the interlink age of response (months and seasons) and descriptive (climatic) data. Multi-nonlinearity among climatic variations were determined on the observations within variables of inflation factor (VIFs) assessment of every climatic factors, and a threshold value of $<5$ is designated to eliminate the extremely collinear descriptive variations. The ultimate CCA model was included of four types of predictions such as minimum temperature, wind speed, and soil moisture $(25 \mathrm{~cm}$ below the soil surface) (Fig. 11). A total Variations of 3.45084 was noted in the reproductive phenology response data, about $58.85 \%$ variations were described by the descriptive variables, and the modified explained variations were $84.68 \%$. The first two CCA axes cumulatively explained about $45.6 \%$ variations (Table 2). A significantly higher pseudo-canonical correlation $(r>0.8)$ value was recorded for the first three CCA axes which show that the 
nominated predictions were significant factors, and there is no single significant climatic gradient relatively all the four were significant in one way or another (Table 3).

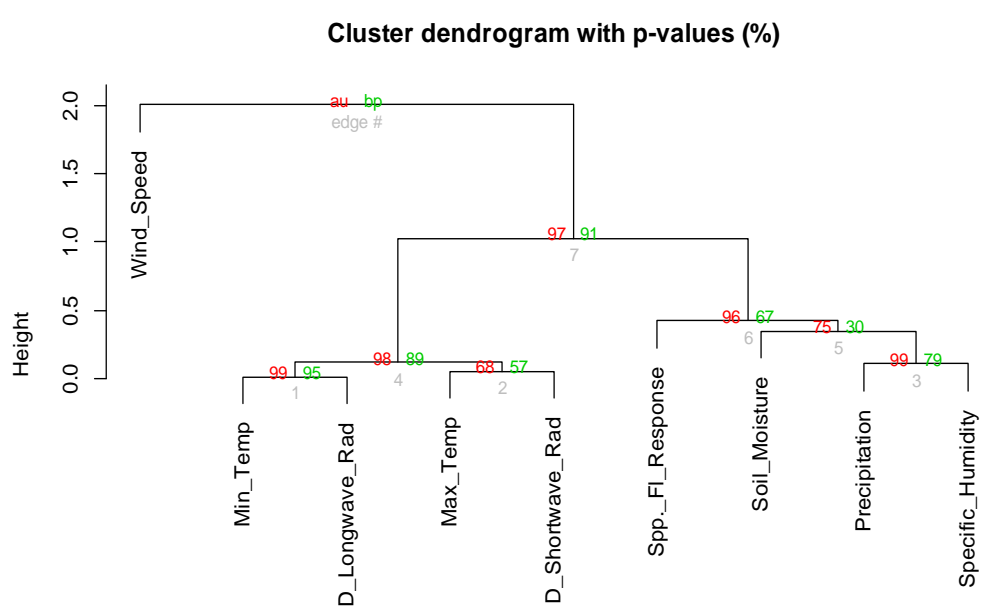

Figure 10. Hierarchical clustering tree of climate and species flowering response variables (Distance: Correlation, Linkage: Ward) with AU/BP\% values $(n=17)$

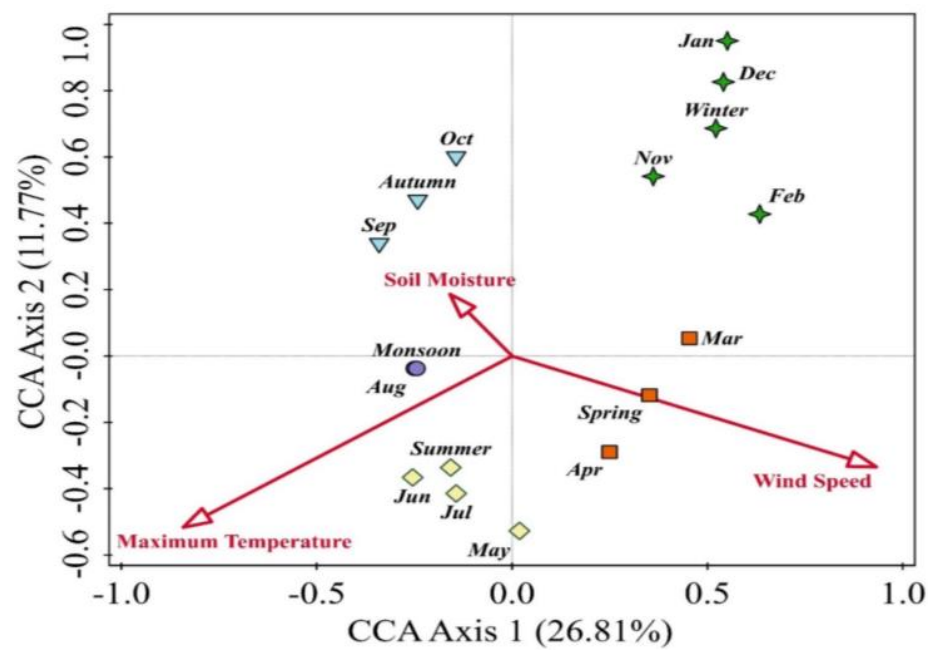

Figure 11. Canonical correspondence analysis biplot depicting the interrelationships of climate and flowering phenological samples (months and seasons) in the study area

Table 2. CCA summary table

\begin{tabular}{c|c|c}
\hline Statistic & Axis 1 & Axis 2 \\
\hline Eigenvalues & 0.9252 & 0.406 \\
Explained variation (cumulative) & 26.81 & 38.58 \\
Pseudo-canonical correlation & 0.9797 & 0.8384 \\
Explained fitted variation (cumulative) & 58.85 & 84.68 \\
\hline Total variations & \multicolumn{2}{|c}{3.45084} \\
Sum of canonical eigenvalues & \multicolumn{2}{|c}{1.57358304} \\
Explained variation \% & \multicolumn{2}{|c}{45.6} \\
Unexplained variation \% & \multicolumn{2}{|c}{54.4} \\
\hline
\end{tabular}


Table 3. Canonical correspondence analysis numerical results showing the order of importance of studied climatic variables ( $p$-values were corrected by using False Discovery Rate method)

\begin{tabular}{|c|c|c|c|c|}
\hline \multicolumn{5}{|c|}{ 1. Simple term effects: } \\
\hline Variable & Explains \% & pseudo-F & $\mathbf{P}$ & $P(\mathbf{a d j})$ \\
\hline Wind speed $(\mathrm{M} / \mathrm{Sec})$ & 24.7 & 4.9 & 0.002 & 0.0032 \\
\hline Min. temperature ${ }^{\circ} \mathrm{C}$ & 24.3 & 4.8 & 0.002 & 0.0032 \\
\hline Downward long wave radiation $\left(\mathrm{W} / \mathrm{M}^{2}\right)$ & 23.4 & 4.6 & 0.002 & 0.0032 \\
\hline Max. temperature ${ }^{\circ} \mathrm{C}$ & 22.3 & 4.3 & 0.002 & 0.0032 \\
\hline Specific humidity $(\mathrm{g} / \mathrm{kg})$ & 21.2 & 4 & 0.002 & 0.0032 \\
\hline Downward shortwave radiation $\left(\mathrm{W} / \mathrm{M}^{2}\right)$ & 15.7 & 2.8 & 0.004 & 0.00533 \\
\hline Precipitation $(\mathrm{mm})$ & 10.2 & 1.7 & 0.056 & 0.064 \\
\hline Soil moisture $(5 \mathrm{~cm}$; in fraction $)$ & 7.6 & 1.2 & 0.234 & 0.234 \\
\hline \multicolumn{5}{|c|}{ 2. Conditional term effects: } \\
\hline Wind speed $(\mathrm{M} / \mathrm{Sec})$ & 24.7 & 4.9 & 0.002 & 0.003 \\
\hline Max. temperature ${ }^{\circ} \mathrm{C}$ & 13.3 & 3 & 0.002 & 0.003 \\
\hline Soil moisture $(5 \mathrm{~cm}$; in fraction $)$ & 7.5 & 1.8 & 0.045 & 0.05 \\
\hline
\end{tabular}

\section{Discussion}

\section{Floristic classification and its importance}

The study area District Jhelum, Punjab, Pakistan contains hills, Jhelum river flows through it, mostly forest cover, scrub lands, range lands and little part of salt range. The area is unique due to versatile geography, variable ecology and rich soil composition. It was observed that the district contains maximum vegetation cover, species richness and floristic diversity. The conducted study aimed to document the floristic composition of the study area along with diverse features counting flowering phenology and reproductive phenological response of the vascular and non-vascular plant species with respect to basic climatic variables.

In the study area, a total of 401 vascular and 1 non-vascular plant species were recorded. The obtained results of family importance value showed that the leading plant family was Poaceae with 59 species followed by Leguminosae (57 spp.), Amaranthaceae (27 spp.) and Solanaceae (19 sp.) while the leading genus was Euphorbia (10 spp.,) followed by Brassica (7 spp.), and Heliotropium, Acacia, and Solanum (6 spp. each). The conducted study was similar to the floristic composition of Muzaffarabad district, Azad Jammu and Kashmir, Pakistan published by Khan et al., 2015, who explored that the leading plant family was Compositae (69 spp.), followed by Poaceae (57 spp.), Leguminosae (54 spp.), Lamiaceae (42 spp.) and Rosaceae (29 spp.); whereas the prominent genus was Euphorbia (10 spp.), followed by Cyperus, Ficus, Geranium and Prunus (7 spp. each). Identical discoveries with floristic composition of Qalagai hills, Kabal valley Swat directed by Ilyas et al., 2013, the Poaceae (22 spp.) was the leading plant family followed by Compositae (16 spp.) and Lamiaceae (14 spp.). In the parallel style Shaheen et al., 2015 quantified 65 plant species of 26 families from western Himalayan subtropical forest stands of Kashmir in which Poaceae (8 spp.) was the prominent family followed by Compositae (6 spp.) and Lamiaceae ( $2 \mathrm{spp}$.) was typically equivalent to the presented discoveries. Comparable outcomes from Shahbaz Garhi, district Mardan, Pakistan by Khan et al., 2014, showed Poaceae (15 pp.) as the prominent 
family followed by Compositae (14 spp.). The identical survey was documented from district Bagh of Azad Jammu and Kasmir by Tanvir et al., 2014 and reported Poaceae (42 spp.) as the leading plant family followed by Compositae (11 spp.). Khan et al., 2015 recorded Poaceae (54 spp.) as the leading family followed by Compositae (33 app.) and Lamiaceae (23 spp.), and closely match with this study. Khan et al., 2017 described same findings that Poaceae was the prominent family comprised of 20 species followed by Lamiaceae (16 spp.) and Compositae (14 spp.), from Swat Ranizai, district Malakand, Khyber Pakhtunkhwa, Pakistan. Poaceae and Compositae are leading due to widespread ecological amplitude with diverse habitats (Ibrahim et al., 2019).

Traditional uses of 149 species belonging to 60 genera and 16 tribes of 5 sub families of Poaceae were recorded by Majeed et al., 2020, from Punjab Province, Pakistan. Hussain, 2009 documented 120 plant species belonging to 46 families, and detected Poaceae as the leading family with 14 plant species also match with this study. Similar results were presented by Shaheen et al., 2014, from Santh Saroola Kotli Sattian, Rawalpindi, Pakistan, who recorded 106 species, Poaceae family was dominant with 21 spp., followed by Asteraceae (19 spp.), Fabaceae (15 spp.), Euphorbiaceae, Lamiaceae (7 spp., each). Umair et al., 2019 recorded similar results, as 129 plant species belonging to 59 families were examined and Poaceae with 13 plants species was the leading family, from Chenab riverine area, Punjab province Pakistan. Amjad et al., 2016 presented similar results from Nikyal valley, Azad Jammu and Kashmir, Pakistan, who recorded 110 species belonging to 51 families and 98 genera. Poaceae (18 spp.) was the leading family followed by Asteraceae (10 spp.), Lamiaceae (8 spp.) and Fabaceae (7 spp.). Zahoor et al., 2017 investigated 96 plants belonging to 34 families from district Sheikhupura, province Punjab, Pakistan and Poaceae was the dominant family with 16 spp. followed by Fabaceae 15 spp. results were similar to the present study. Plant species of the Poaceae family are not only used as fodder and forage but also contribute substantially to the treatment of various health disorders, particularly in livestock (Majeed et al., 2020).

\section{Climatic determinants of flowering phenology}

The flowering response results indicated that majority of plant species flowered during the months of March (43.07\%), followed by April (39.36\%) and August (39.11\%). The minimum phenological response was noted in the month of January $(1.24 \%)$, December $(1.24 \%)$ and November $(1.73 \%)$.

The timing of flowering response as presented above was found highly correlated with the climatic variations (like temperature and monsoon rainfall) of the study area. A constrained unimodal ordination such as CCA was applied to check three predictors including minimum temperature, humidity, and soil moisture $(25 \mathrm{~cm}$ below the soil surface).

According to the results of conditional (unique) term effect testing, mean maximum temperature was shown as a significant factor of the phenological response followed by soil moisture and wind speed. The majority of plant species are found in flowering stage during July and August months in the Western Himalayan regions of India and Pakistan (Vashistha et al., 2009; Khan et al., 2018), and strikingly match with our findings.

Likewise, the importance of temperature to the plants phenological responses, our results are similar as stated in several explorations (Badeck et al., 2004; Ahas and Aasa, 2006; Estrella and Menzel, 2006; Peñuelas et al., 2009) mostly in higher altitudinal areas of the World. 
Minimum temperature was recorded as significant as maximum temperature in the research area similar to Khan et al., 2018. Furthermore, rainfall was discovered as another main element of the phenological response (Pearson, 2019), the similar influence of rainfall on both spring and fall flowering events was reported from Southeastern United State of America. Our results match with Heydel et al., 2015; and Khan et al., 2018, that is maximum flowering species were recorded during four months (March, April, august, September) due to favorable climatic conditions. Whereas minimum flowering species were documented during three months (January, November and December) due to severe climatic conditions. Many explorations showed that in hilly areas, maximum flowering species were noted due to optimum climatic variables to support the phenomenon (Yadav and Yadav, 2008; Tooke, 2010). So it was assessed that months of May, June and July are appropriate regarding day length and temperature. The highest phenological response of plant species during months of March, April, August and September which can also be linked with maximum rainfall in these months (Summer and monsoon seasons) resulting in higher soil moisture. While, rare plant species were also found in flowering stage in November to January (in winters) due to severity in environmental conditions during mentioned months. Climatic variations might be harmful in general but mainly useful to rare and widespread plant species of this versatile, unique but delicate ecosystem of Jhelum district, Punjab, Pakistan.

\section{Conclusions and recommendations}

The research area district Jhelum resulted higher degree of plant species richness features of mostly diverse and rich flora in Punjab, Pakistan. The leading plant family was Poaceae followed by Leguminosae, Amaranthaceae, Solanaceae while the leading genus was Euphorbia followed by Brassica, Heliotropium, Acacia, Solanum, which proposed that the research area is under heavy anthropogenic pressure and harbors unique climatic environments. As concerned with the reproductive phenological response of the plant species, minimum temperature, wind speed, precipitation and specific humidity are the significant climatic determinants. The study resulted that the temperature is the leading effective feature observing the phenology of the plant species. It was estimated that increase or decrease in temperature showed specific association with pattern of phenology. Response of phenology also showed month and season wise correlation. Suddenly increase in temperature might be dangerous mainly to threatened and widespread flora of the area. The study area needs active supervision and protection strategies done with the participation of the indigenous population. The floristic study and phenology of plant species was explored for the first time. Consequently, the current research serves valuable information in future botanical investigation, and for plant reserve managing and preservation effort in the area. Future research studies should be linked to measurement of continuing climate variations. Under changing climatic conditions, the spread of invasive alien plant species is needed to be controlled to save the ecological niche of indigenous wild flora in the area.

Acknowledgments. This research work is part of the $\mathrm{PhD}$ thesis of the first author. Special thanks are due to all study participants of the different local groups who generously shared their knowledge about local names of wild plant species.

Conflict of interests. The authors declare that they have no conflict of interests. 


\section{REFERENCES}

[1] Ahas, R., Aasa, A. (2006): The effects of climate change on the phenology of selected Estonian plant, bird and fish populations. - International Journal of Biometeorology 51(1): $17-26$.

[2] Ali, S. I., Nasir, Y. J. (1989): Flora of Pakistan (fascicle series) - Islamabad, Karachi.

[3] Ali, S. I., Qaiser, M. (1995): Flora of Pakistan (fascicles series) - Islamabad, Karachi.

[4] Altaf, M., Umair, M., Abbasi, A. R., Muhammad, N., Abbasi, A. M. (2018): Ethnomedicinal applications of animal species by the local communities of Punjab, Pakistan. - Journal of Ethnobiology and Ethnomedicine 14(1): 55.

[5] Amber, K., Khan, K. R.., Shah, A. H., Farooq, M., Lodhi, M. H., Shah, G. M. (2019): A comprehensive survey of floristic diversity evaluating the role of institutional gardening in conservation of plant biodiversity. - International Journal of Biosciences 14(3): 325-339.

[6] Amjad, M. S., Arshad, M., Sadaf, H. M., Akrim, F., Arshad, A. (2016): Floristic composition, biological spectrum and conservation status of the vegetation in Nikyal valley, Azad Jammu and Kashmir. - Asian Pacific Journal of Tropical Disease 6(1): 63-69.

[7] Anderson, J. T., Inouye, D. W., McKinney, A. M., Colautti, R. I., Mitchell-Olds, T. (2012): Phenotypic plasticity and adaptive evolution contribute to advancing flowering phenology in response to climate change. - Proceedings of the Royal Society B: Biological Sciences 279(1743): 3843-3852.

[8] Badeck, F. W., Bondeau, A., Böttcher, K., Doktor, D., Lucht, W., Schaber, J., Sitch, S. (2004): Responses of spring phenology to climate change. - New Phytologist 162(2): 295309.

[9] Bertin, R. I. (2008): Plant phenology and distribution in relation to recent climate change. The Journal of the Torrey Botanical Society 135(1): 126-146.

[10] Bodin, F., Morlat, R. (2006): Characterization of viticultural terroirs using a simple field model based on soil depth I. Validation of the water supply regime, phenology and vine vigour, in the Anjou vineyard (France). - Plant and Soil 281(1-2): 37-54.

[11] Both, C., Bouwhuis, S., Lessells, C. M., Visser, M. E. (2006): Climate change and population declines in a long-distance migratory bird. - Nature 441(7089): 81-83.

[12] Buyantuyev, A., Wu, J. (2012): Urbanization diversifies land surface phenology in arid environments: interactions among vegetation, climatic variation, and land use pattern in the Phoenix metropolitan region, USA. - Landscape and Urban Planning 105(1-2): 149-159.

[13] Cain, S. A., Castro, G. D. O. (1960): Manual of Vegetation Analysis. - Harper, New York.

[14] Calinger, K. M., Queenborough, S., Curtis, P. S. (2013): Herbarium specimens reveal the footprint of climate change on flowering trends across north-central North America. Ecology Letters 16(8): 1037-1044.

[15] Chambers, L. E., Altwegg, R., Barbraud, C., Barnard, P., Beaumont, L. J., Crawford, R. J., Durant, J. M., Hughes, L., Keatley, M. R., Low, M., Morellato, P. C. (2013): Phenological changes in the southern hemisphere. - PloS One 8(10): 75514.

[16] Change, I. P. O. C. (2007): Climate change 2007: the physical science basis. - Agenda 6(07): 333.

[17] Chen, J., Luo, Y., Chen, Y., Felton, A. J., Hopping, K. A., Wang, R. W., Niu, S., Cheng, X., Zhang, Y., Cao, J., Olesen, J. E. (2020): Plants with lengthened phenophases increase their dominance under warming in an alpine plant community. - Science of the Total Environment: 138891.

[18] Cleland, E. E., Chuine, I., Menzel, A., Mooney, H. A., Schwartz, M. D. (2007): Shifting plant phenology in response to global change. - Trends in Ecology \& Evolution 22(7): 357365 .

[19] Cleland, E. E., Allen, J. M., Crimmins, T. M., Dunne, J. A., Pau, S., Travers, S. E., Zavaleta, E. S., Wolkovich, E. M. (2012): Phenological tracking enables positive species responses to climate change. - Ecology 93(8): 1765-1771. 
[20] Cleverly, J., Eamus, D., Coupe, N. R., Chen, C., Maes, W., Li, L., Faux, R., Santini, N. S., Rumman, R., Yu, Q., Huete, A. (2016): Soil moisture controls on phenology and productivity in a semi-arid critical zone. - Science of the Total Environment 568: 12271237.

[21] Cornelius, C., Estrella, N., Franz, H., Menzel, A. (2013): Linking altitudinal gradients and temperature responses of plant phenology in the Bavarian Alps. - Plant Biology 15: 57-69.

[22] Crabbe, R. A., Dash, J., Rodriguez-Galiano, V. F., Janous, D., Pavelka, M., Marek, M. V. (2016): Extreme warm temperatures alter forest phenology and productivity in Europe. Science of the Total Environment 563: 486-495.

[23] Estrella, N., Menzel, A. (2006): Responses of leaf colouring in four deciduous tree species to climate and weather in Germany. - Climate Research 32(3): 253-267.

[24] Forrest, J. R. (2015): Plant-pollinator interactions and phenological change: what can we learn about climate impacts from experiments and observations? - Oikos 124(1): 4-13.

[25] Francioli, D., Schulz, E., Buscot, F., Reitz, T. (2018): Dynamics of soil bacterial communities over a vegetation season relate to both soil nutrient status and plant growth phenology. - Microbial Ecology 75(1): 216-227.

[26] Ge, Q., Wang, H., Rutishauser, T., Dai, J. (2015): Phenological response to climate change in China: a meta-analysis. - Global Change Biology 21(1): 265-274.

[27] Gill, A. L., Gallinat, A. S., Sanders-DeMott, R., Rigden, A. J., Short Gianotti, D. J., Mantooth, J. A., Templer, P. H. (2015): Changes in autumn senescence in northern hemisphere deciduous trees: a meta-analysis of autumn phenology studies. - Annals of Botany 116(6): 875-888.

[28] Godoy, O., Richardson, D. M., Valladares, F., Castro-Díez, P. (2009): Flowering phenology of invasive alien plant species compared with native species in three Mediterranean-type ecosystems. - Annals of Botany 103(3): 485-494.

[29] Gordo, O., Sanz, J. J. (2005): Phenology and climate change: a long-term study in a Mediterranean locality. - Oecologia 146(3): 484-495.

[30] Hamidov, A., Helming, K., Balla, D. (2016): Impact of agricultural land use in Central Asia: a review. - Agronomy for Sustainable Development 36(1): 6.

[31] Heydel, F., Cunze, S., Bernhardt-Römermann, M., Tackenberg, O. (2015): Seasonal synchronization of seed release phenology promotes long-distance seed dispersal by wind for tree species with medium wind dispersal potential. - Journal of Vegetation Science 26(6): 1090-1101.

[32] Holway, J. G., Ward, R. T. (1965): Phenology of alpine plants in northern Colorado. Ecology 46(1-2): 73-83.

[33] Hulme, P. E. (2011): Contrasting impacts of climate-driven flowering phenology on changes in alien and native plant species distributions. - New Phytologist 189(1): 272-281.

[34] Hussain, T. (2009): A floristic description of flora and ethnobotany of Samahni Valley (AK), Pakistan. - Ethnobotanical Leaflets (7): 6.

[35] Ibrahim, M., Nauman Khan, M., Ali, S., Razzaq, A., Zaman, A., Iqbal, M. (2019): Floristic Composition and Species Diversity of Plant Resources of Rural Area "Takht Bhai" District Mardan, Khyber Pakhtunkhwa, Pakistan. - Medicinal Aromatic Plants (Los Angeles) 8(338): 2167-0412.

[36] Ilyas, M., Qureshi, R., Shinwari, Z. K., Arshad, M., Mirza, S. N. (2013): Some ethnoecological aspects of the plants of Qalagai Hills, Kabal Valley, Swat, Pakistan. International Journal of Agriculture and Biology (Pakistan) 15(5): 1560-8530.

[37] Inouye, D. W. (2008): Effects of climate change on phenology, frost damage, and floral abundance of montane wildflowers. - Ecology 89(2): 353-362.

[38] Iqbal, H., Sher, Z., Khan, Z. U. (2011): Medicinal plants from salt range Pind Dadan Khan, district Jhelum, Punjab, Pakistan. - Journal of Medicinal Plants Research 5(11): 2157-2168.

[39] Keenan, T. F., Richardson, A. D., Hufkens, K. (2020): On quantifying the apparent temperature sensitivity of plant phenology. - New Phytologist 225(2): 1033-1040. 
[40] Khan, M., Hussain, F. and Musharaf, S. (2014): Floristic composition and ecological characteristics of Shahbaz Garhi, District Mardan, Pakistan. - Global Journal of Science Frontier Research 1: 7-17.

[41] Khan, A. M., Qureshi, R., Qaseem, M. F., Munir, M., Ilyas, M., Saqib, Z. (2015): Floristic checklist of district Kotli, Azad Jammu \& Kashmir. - Pakistan Journal of Botany 47(5): 1957-1968.

[42] Khan, A. M., Qureshi, R., Qaseem, M. F., Ahmad, W., Saqib, Z., Habib, T. (2016): Status of basic taxonomic skills in botanical articles related to Azad Jammu and Kashmir, Pakistan: a review. - Journal of Bioresource Management 3(3): 22-54.

[43] Khan, A., Khan, N., Ali, K., Rahman, I. U. (2017): An assessment of the floristic diversity, life-forms and biological spectrum of vegetation in Swat Ranizai, District Malakand, Khyber Pakhtunkhwa, Pakistan. - Science Technology Development 36(2): 61-78.

[44] Khan, A. M., Qureshi, R., Arshad, M., Mirza, S. N. (2018): Climatic and flowering phenological relationships of western Himalayan flora of Muzaffarabad district, Azad Jammu and Kashmir, Pakistan. - Pakistan Journal Botany 50(3): 1093-1112.

[45] Khan, A. M., Qureshi, R., Saqib, Z. (2019a): Multivariate analyses of the vegetation of the western Himalayan forests of Muzaffarabad district, Azad Jammu and Kashmir, Pakistan. Ecological Indicators 104: 723-736. https://doi.org/10.1016/j.ecolind.2019.05.048

[46] Khan, A. M., Qureshi, R., Saqib, Z., Munir, M., Shaheen, H., Habib, T., Dar, M. E. I. U., Fatimah, H., Afza, R., Hussain, M. (2019b): A first ever detailed ecological exploration of the western Himalayan forests of Sudhan Gali and Ganga Summit, Azad Jammu and Kashmir, Pakistan. - Applied Ecology and Environmental Research 17(6): 15477-15505.

[47] Khanduri, V. P., Sharma, C. M. and Singh, S. P. (2008): The effects of climate change on plant phenology. - The Environmentalist 28(2): 143-147.

[48] Kharouba, H. M. and Vellend, M. (2015): Flowering time of butterfly nectar food plants is more sensitive to temperature than the timing of butterfly adult flight. - Journal of Animal Ecology 84(5): 1311-1321.

[49] Kolb, A., Ehrlen, J., Eriksson, O. (2007): Ecological and evolutionary consequences of spatial and temporal variation in pre-dispersal seed predation. - Perspectives in Plant Ecology, Evolution and Systematics 9(2): 79-100.

[50] Lesica, P. and Kittelson, P. M. (2010): Precipitation and temperature are associated with advanced flowering phenology in a semi-arid grassland. - Journal of Arid Environments 74(9): 1013-1017.

[51] Liu, Q., Fu, Y. H., Zeng, Z., Huang, M., Li, X., Piao, S. (2016a): Temperature, precipitation, and insolation effects on autumn vegetation phenology in temperate China. Global Change Biology 22(2): 644-655.

[52] Liu, Q., Fu, Y. H., Zhu, Z., Liu, Y., Liu, Z., Huang, M., Janssens, I. A., Piao, S. (2016b): Delayed autumn phenology in the Northern Hemisphere is related to change in both climate and spring phenology. - Global Change Biology 22(11): 3702-3711.

[53] Luo, Z., Sun, O. J., Ge, Q., Xu, W., Zheng, J. (2007): Phenological responses of plants to climate change in an urban environment. - Ecological Research 22(3): 507-514.

[54] Ma, X., Huete, A., Yu, Q., Coupe, N. R., Davies, K., Broich, M., Ratana, P., Beringer, J., Hutley, L. B., Cleverly, J., Boulain, N. (2013): Spatial patterns and temporal dynamics in savanna vegetation phenology across the North Australian Tropical Transect. - Remote Sensing of Environment 139: 97-115.

[55] Majeed, M., Bhatti, K. H., Amjad, M. S., Abbasi, A. M., Bussmann, R. W., Nawaz, F., Rashid, A., Mehmood, A., Mahmood, M., Khan, W. M., Ahmad, K. S. (2020): Ethnoveterinary uses of Poaceae in Punjab, Pakistan. - PloS One 15(11): 0241705.

[56] Majeed, M., Bhatti, K. H., Pieroni, A., Sõukand, R., Bussmann, R. W., Khan, A. M., Chaudhari, S. K., Aziz, M. A., Amjad, M. S. (2021). Gathered Wild Food Plants among Diverse Religious Groups in Jhelum District, Punjab, Pakistan. - Foods 10(3): 594. 
[57] Matthews, E. R., Mazer, S. J. (2016): Historical changes in flowering phenology are governed by temperature $\times$ precipitation interactions in a widespread perennial herb in western North America. - New Phytologist 210(1): 157-167.

[58] McEwan, R. W., Brecha, R. J., Geiger, D. R., John, G. P. (2011): Flowering phenology change and climate warming in southwestern Ohio. - Plant Ecology 212(1): 55-61.

[59] Meier, N., Rutishauser, T., Pfister, C., Wanner, H., Luterbacher, J. (2007): Grape harvest dates as a proxy for Swiss April to August temperature reconstructions back to AD 1480.Geophysical Research Letters 34(20).

[60] Menzel, A., Sparks, T. H., Estrella, N., Koch, E., Aasa, A., Ahas, R., Alm-Kübler, K., Bissolli, P., Braslavská, O. G., Briede, A., Chmielewski, F. M. (2006): European phenological response to climate change matches the warming pattern. - Global Change Biology 12(10): 1969-1976.

[61] Mittermeier, J. C., Roll, U., Matthews, T. J., Grenyer, R. (2019): A season for all things: phenological imprints in Wikipedia usage and their relevance to conservation. - PLoS Biology 17(3): 3000146.

[62] Morisette, J. T., Richardson, A. D., Knapp, A. K., Fisher, J. I., Graham, E. A., Abatzoglou, J., Wilson, B. E., Breshears, D. D., Henebry, G. M., Hanes, J. M., Liang, L. (2009): Tracking the rhythm of the seasons in the face of global change: phenological research in the 21st century. - Frontiers in Ecology and the Environment 7(5): 253-260.

[63] Mukul, S. A., Uddin, M. B., Tito, M. R. (2007): Medicinal plant diversity and local healthcare among the people living in and around a conservation area of Northern Bangladesh. - International Journal of Forest Usufructs Management 8(2): 50-63.

[64] Mushtaq, M. U., Gull, S., Shad, M. A., Akram, J. (2011): Socio-demographic correlates of the health-seeking behaviours in two districts of Pakistan's Punjab province. - JPMAJournal of the Pakistan Medical Association 61(12): 1205.

[65] Nandintsetseg, B., Shinoda, M. (2011): Seasonal change of soil moisture in Mongolia: its climatology and modelling. - International Journal of Climatology 31(8): 1143-1152.

[66] Neil, K., Wu, J. (2006): Effects of urbanization on plant flowering phenology: a review. Urban Ecosystems 9(3): 243-257.

[67] Neil, K. L., Landrum, L., Wu, J. (2010): Effects of urbanization on flowering phenology in the metropolitan phoenix region of USA: findings from herbarium records. - Journal of Arid Environments 74(4): 440-444.

[68] Okusanya, O. T., Shonubi, O. O., Bello, O., Bamidele, J. F. (2016): Variation in flowering phenology of Cassia fistula Linn. Population in Ota, Ogun state, Nigeria. - Ife Journal of Science 18(4): 887-894.

[69] Parmesan, C. (2006): Ecological and evolutionary responses to recent climate change. Annual Review of Ecology, Evolution, and Systematics 37: 637-669.

[70] Parmesan, C., Yohe, G. (2003): A globally coherent fingerprint of climate change impacts across natural systems. - Nature 421(6918): 37-42.

[71] Pausas, J. G., Austin, M. P. (2001): Patterns of plant species richness in relation to different environments: an appraisal. - Journal of Vegetation Science 12(2): 153-166.

[72] Pearson, K. D. (2019): Spring-and fall-flowering species show diverging phenological responses to climate in the Southeast USA. - International Journal of Biometeorology 63(4): 481-492.

[73] Peña-Barragán, J. M., Ngugi, M. K., Plant, R. E., Six, J. (2011): Object-based crop identification using multiple vegetation indices, textural features and crop phenology. Remote Sensing of Environment 115(6): 1301-1316.

[74] Peñuelas, J., Filella, I., Zhang, X., Llorens, L., Ogaya, R., Lloret, F., Comas, P., Estiarte, M., Terradas, J. (2004): Complex spatiotemporal phenological shifts as a response to rainfall changes. - New Phytologist 161(3): 837-846.

[75] Petry, W. K., Soule, J. D., Iler, A. M., Chicas-Mosier, A., Inouye, D. W., Miller, T. E., Mooney, K. A. (2016): Sex-specific responses to climate change in plants alter population sex ratio and performance. - Science 353(6294): 69-71. 
[76] Piao, S., Liu, Q., Chen, A., Janssens, I. A., Fu, Y., Dai, J., Liu, L., Lian, X., Shen, M., Zhu, X. (2019): Plant phenology and global climate change: current progresses and challenges. Global Change Biology 25(6): 1922-1940.

[77] Prevéy, J., Vellend, M., Rüger, N., Hollister, R. D., Bjorkman, A. D., Myers-Smith, I. H., Elmendorf, S. C., Clark, K., Cooper, E. J., Elberling, B., Fosaa, A. M. (2017): Greater temperature sensitivity of plant phenology at colder sites: implications for convergence across northern latitudes. - Global Change Biology 23(7): 2660-2671.

[78] Qureshi, R., Maqsood, M., Arshad, M., Chaudhry, A. K. (2011): Ethnomedicinal uses of plants by the people of Kadhi areas of Khushab, Punjab, Pakistan. - Pakistan Journal of Botany 43(1): 121-133.

[79] R-Core-Team (2014): R: a language and environment for statistical computing. - R Foundation for Statistical Computing 2014, Vienna, Austria. http://www.Rproject.org/.

[80] Richardson, A. D., Keenan, T. F., Migliavacca, M., Ryu, Y., Sonnentag, O., Toomey, M. (2013): Climate change, phenology, and phenological control of vegetation feedbacks to the climate system. - Agricultural and Forest Meteorology 169: 156-173.

[81] Rosenzweig, C., Casassa, G., Karoly, D. J., Imeson, A., Liu, C., Menzel, A., Rawlins, S., Root, T. L., Seguin, B., Tryjanowski, P., Parry, M. L. (2007): Assessment of Observed Changes and Responses in Natural and Managed Systems. - In: Parry, M. L. et al. (eds.) Climate Change 2007: Impacts, Adaptation and Vulnerability. Contribution of Working Group II to the Fourth Assessment Report of the Intergovernmental Panel on Climate Change. Cambridge University Press, Cambridge, UK, pp. 79-131.

[82] Schwartz, M. D., Ault, T. R., Betancourt, J. L. (2013): Spring onset variations and trends in the continental United States: past and regional assessment using temperature-based indices. - International Journal of Climatology 33(13): 2917-2922.

[83] Shah, G. U. D., Bhatti, M. N., Iftikhar, M., Qureshi, M. I., Zaman, K. (2013): Implementation of technology acceptance model in e-learning environment in rural and urban areas of Pakistan. - World Applied Sciences Journal 27(11): 1495-1507.

[84] Shaheen, H., Qureshi, R., Iqbal, S., Qasem, M. F. (2014): Seasonal availability and palatability of native flora of Santh Saroola Kotli Sattian, Rawalpindi, Pakistan. - African Journal of Plant Science 8(2): 92-102.

[85] Shaheen, H., Malik, N. M., Dar, M. E. U. I. (2015): Species composition and community structure of subtropical forest stands in western Himalayan foothills of Kashmir. - Pakistan Journal of Botany 47(6): 2151-2160.

[86] Shen, M., Tang, Y., Chen, J., Zhu, X., Zheng, Y. (2011): Influences of temperature and precipitation before the growing season on spring phenology in grasslands of the central and eastern Qinghai-Tibetan Plateau. - Agricultural and Forest Meteorology 151(12): 17111722.

[87] Shen, M., Piao, S., Dorji, T., Liu, Q., Cong, N., Chen, X., An, S., Wang, S., Wang, T., Zhang, G. (2015): Plant phenological responses to climate change on the Tibetan Plateau: research status and challenges. - National Science Review 2(4): 454-467.

[88] Shen, M., Piao, S., Chen, X., An, S., Fu, Y. H., Wang, S., ... Janssens, I. A. (2016): Strong impacts of daily minimum temperature on the green-up date and summer greenness of the Tibetan Plateau. - Global Change Biology 22(9): 3057-3066.

[89] Staehlin, B. M., Fant, J. B. (2015): Climate change impacts on seedling establishment for a threatened endemic thistle, Cirsium pitcheri. - The American Midland Naturalist 173(1): 47-60.

[90] Sun, W., Song, X., Mu, X., Gao, P., Wang, F., Zhao, G. (2015): Spatiotemporal vegetation cover variations associated with climate change and ecological restoration in the Loess Plateau. - Agricultural and Forest Meteorology 209: 87-99.

[91] Tadey, M. (2020): Reshaping phenology: grazing has stronger effects than climate on flowering and fruiting phenology in desert plants. - Perspectives in Plant Ecology, Evolution and Systematics 42: 125501. 
[92] Tanvir, M., Murtaza, G., Ahmad, K. S., Salman, M. (2014): Floral diversity of District Bagh, Azad Jammu and Kashmir Pakistan. - Universal Journal of Plant Science 2(1): 1-13.

[93] Ter Braak, C. J. F., Šmilauer, P. (2012): Canoco 5, Windows Release (5.00). Software for Mutivariate Data Exploration, Testing, and Summarization. - Biometris, Plant Research International, Wageningen.

[94] Thomson, J. D. (2010): Flowering phenology, fruiting success and progressive deterioration of pollination in an early-flowering geophyte. - Philosophical Transactions of the Royal Society B: Biological Sciences 365(1555): 3187-3199.

[95] Tooke, F., Battey, N. H. (2010): Temperate flowering phenology. - Journal of Experimental Botany 61(11): 2853-2862.

[96] TPL (2013): Onward (continuously updated), The Plant List, Version1.1. http://www.theplantlist.org/ (accessed 15/04/2020).

[97] Umair, M., Altaf, M., Bussmann, R. W., Abbasi, A. M. (2019): Ethnomedicinal uses of the local flora in Chenab riverine area, Punjab province Pakistan. - Journal of Ethnobiology and Ethnomedicine 15(1): 7.

[98] Vashistha, R. K., Rawat, N., Chaturvedi, A. K., Nautiyal, B. P., Prasad, P., Nautiyal, M. C. (2009): An exploration on the phenology of different growth forms of an alpine expanse of North-West Himalaya, India. - New York Science Journal 2(6): 29-41.

[99] Visser, M. E., Caro, S. P., Van Oers, K., Schaper, S. V., Helm, B. (2010): Phenology, seasonal timing and circannual rhythms: towards a unified framework. Philosophical Transactions of the Royal Society. - B: Biological Sciences 365(1555): 3113-3127.

[100] Wang, H., Dai, J., Rutishauser, T., Gonsamo, A., Wu, C., Ge, Q. (2018): Trends and variability in temperature sensitivity of lilac flowering phenology. - Journal of Geophysical Research: Biogeosciences 123(3): 807-817.

[101] Willis, C. G., Ruhfel, B., Primack, R. B., Miller-Rushing, A. J., Davis, C. C. (2008): Phylogenetic patterns of species loss in Thoreau's woods are driven by climate change. Proceedings of the National Academy of Sciences 105(44): 17029-17033.

[102] Wolkovich, E. M., Cleland, E. E. (2011): The phenology of plant invasions: a community ecology perspective. - Frontiers in Ecology and the Environment 9(5): 287-294.

[103] Wolkovich, E. M., Cleland, E. E. (2014): Phenological niches and the future of invaded ecosystems with climate change. - AoB Plants: 6.

[104] Yadav, R. K., Yadav, A. S. (2008): Phenology of selected woody species in a tropical dry deciduous forest in Rajasthan, India. - Tropical Ecology 49(1): 25.

[105] Yang, B., He, M., Shishov, V., Tychkov, I., Vaganov, E., Rossi, S., Ljungqvist, F. C., Bräuning, A., Grießinger, J. (2017): New perspective on spring vegetation phenology and global climate change based on Tibetan Plateau tree-ring data. - Proceedings of the National Academy of Sciences 114(27): 6966-6971.

[106] Yu, F., Price, K. P., Ellis, J., Shi, P. (2003): Response of seasonal vegetation development to climatic variations in eastern central Asia. - Remote Sensing of Environment 87(1): 4254.

[107] Zahoor, M., Yousaf, Z., Aqsa, T., Haroon, M., Saleh, N., Aftab, A., Javed, S., Qadeer, M., Ramazan, H. (2017): An ethnopharmacological evaluation of Navapind and Shahpur Virkanin district Sheikupura, Pakistan for their herbal medicines. - Journal of Ethnobiology and Ethnomedicine 13(1): 27.

[108] Zalamea, M., González, G. (2008): Leaffall phenology in a subtropical wet forest in Puerto Rico: from species to community patterns. - Biotropica 40(3): 295-304.

[109] Zhang, Q., Kong, D., Shi, P., Singh, V. P., Sun, P. (2018): Vegetation phenology on the Qinghai-Tibetan Plateau and its response to climate change (1982-2013). - Agricultural and Forest Meteorology 248: 408-417. 


\section{APPENDIX}

Table A1. Temporal (2010-2019) variations in the climatic data (Mean \pm SD (Min-Max)) of district Jhelum, Punjab, Pakistan

\begin{tabular}{|c|c|c|c|c|c|c|c|c|}
\hline Months & Min Temp & Max Temp & Precipitation & Wind speed & Specific humidity & Soil moisture & D-Shortwave-Rad & D-Longwave-Rad \\
\hline $\begin{array}{c}\text { January } \\
(2010-2019)\end{array}$ & $\begin{array}{c}5.24 \pm 0.81 \\
(3.98-6.53)\end{array}$ & $\begin{array}{c}18 \pm 1.75 \\
(15.81-21.37)\end{array}$ & $\begin{array}{l}47.74 \pm 54.85 \\
(0.4-178.23)\end{array}$ & $\begin{array}{c}2.49 \pm 0.17 \\
(2.29-2.74)\end{array}$ & $\begin{array}{c}4.07 \pm 0.91 \\
(2.59-5.59)\end{array}$ & $\begin{array}{c}0.24 \pm 0.04 \\
(0.17-0.28)\end{array}$ & $\begin{array}{c}137.35 \pm 17.72 \\
(102.79-156.34)\end{array}$ & $\begin{array}{c}285.19 \pm 10.4 \\
(273.15-305.42)\end{array}$ \\
\hline $\begin{array}{c}\text { February } \\
(2010-2019)\end{array}$ & $\begin{array}{c}7.32 \pm 1.15 \\
(5.24-8.64)\end{array}$ & $\begin{array}{c}19.3 \pm 2.44 \\
(16.42-23.18)\end{array}$ & $\begin{array}{c}113.9 \pm 72.6 \\
(9.08-239.44) \\
\end{array}$ & $\begin{array}{c}2.66 \pm 0.18 \\
(2.44-2.94)\end{array}$ & $\begin{array}{c}5.83 \pm 0.81 \\
(4.75-6.81)\end{array}$ & $\begin{array}{c}0.3 \pm 0.04 \\
(0.24-0.35)\end{array}$ & $\begin{array}{c}156.06 \pm 20.95 \\
(125.65-195.67)\end{array}$ & $\begin{array}{c}306.07 \pm 8.92 \\
(292.52-317.13)\end{array}$ \\
\hline $\begin{array}{c}\text { March } \\
(2010-2019)\end{array}$ & $\begin{array}{c}11.36 \pm 1.31 \\
(9.96-13.92)\end{array}$ & $\begin{array}{c}25.3 \pm 2.86 \\
(21.53-30.59)\end{array}$ & $\begin{array}{l}117.59 \pm 98.66 \\
(12.1-283.46)\end{array}$ & $\begin{array}{c}2.62 \pm 0.16 \\
(2.39-2.87)\end{array}$ & $\begin{array}{c}7.2 \pm 1.13 \\
(4.92-8.39)\end{array}$ & $\begin{array}{l}0.29 \pm 0.06 \\
(0.2-0.37)\end{array}$ & $\begin{array}{c}215.35 \pm 19.93 \\
(176.04-238.07)\end{array}$ & $\begin{array}{c}328.84 \pm 7.66 \\
(316.34-342.61)\end{array}$ \\
\hline $\begin{array}{c}\text { April } \\
(2010-2019)\end{array}$ & $\begin{array}{c}16.49 \pm 1.03 \\
(15.04-18.46) \\
\end{array}$ & $\begin{array}{c}31.99 \pm 2.7 \\
(28.93-37.35) \\
\end{array}$ & $\begin{array}{c}104.04 \pm 55.51 \\
(19.16-177.93) \\
\end{array}$ & $\begin{array}{c}2.58 \pm 0.31 \\
(2.34-3.25)\end{array}$ & $\begin{array}{c}8.21 \pm 1.2 \\
(6.72-10.46) \\
\end{array}$ & $\begin{array}{c}0.26 \pm 0.05 \\
(0.16-0.33)\end{array}$ & $\begin{array}{c}268.88 \pm 16.83 \\
(228.62-288.59)\end{array}$ & $\begin{array}{c}357.86 \pm 5.73 \\
(351.28-365.76)\end{array}$ \\
\hline $\begin{array}{c}\text { May } \\
(2010-2019)\end{array}$ & $\begin{array}{l}21.48 \pm 0.87 \\
(20.15-22.7)\end{array}$ & $\begin{array}{c}38.79 \pm 1.74 \\
(35.16-40.95)\end{array}$ & $\begin{array}{c}56.02 \pm 40.76 \\
(5.83-133.89)\end{array}$ & $\begin{array}{c}2.51 \pm 0.26 \\
(2.14-2.99)\end{array}$ & $\begin{array}{c}7.59 \pm 1.13 \\
(5.96-9.72)\end{array}$ & $\begin{array}{c}0.21 \pm 0.04 \\
(0.16-0.27)\end{array}$ & $\begin{array}{c}307.76 \pm 10.62 \\
(287.96-318.56)\end{array}$ & $\begin{array}{c}381.49 \pm 7.98 \\
(371.25-393.43)\end{array}$ \\
\hline $\begin{array}{c}\text { June } \\
(2010-2019)\end{array}$ & $\begin{array}{c}25.49 \pm 0.89 \\
(24.24-27.23) \\
\end{array}$ & $\begin{array}{c}42.06 \pm 1.44 \\
(39.4-44.29) \\
\end{array}$ & $\begin{array}{c}51.78 \pm 49.11 \\
(3.66-155.66) \\
\end{array}$ & $\begin{array}{c}2.19 \pm 0.12 \\
(2.05-2.38)\end{array}$ & $\begin{array}{c}9.38 \pm 2.08 \\
(5.88-12.33)\end{array}$ & $\begin{array}{c}0.19 \pm 0.03 \\
(0.15-0.23)\end{array}$ & $\begin{array}{c}308.9 \pm 10.75 \\
(290.16-325.21)\end{array}$ & $\begin{array}{c}411.44 \pm 9.36 \\
(395.77-427.8)\end{array}$ \\
\hline $\begin{array}{c}\text { July } \\
(2010-2019) \\
\end{array}$ & $\begin{array}{c}26.53 \pm 0.73 \\
(25.73-27.7) \\
\end{array}$ & $\begin{array}{c}38.17 \pm 2.01 \\
(35.78-41.92) \\
\end{array}$ & $\begin{array}{l}233.75 \pm 131.86 \\
(66.36-483.97) \\
\end{array}$ & $\begin{array}{l}2.16 \pm 0.19 \\
(1.9-2.45) \\
\end{array}$ & $\begin{array}{c}16.48 \pm 1.63 \\
(14.26-19.35) \\
\end{array}$ & $\begin{array}{c}0.28 \pm 0.04 \\
(0.23-0.34) \\
\end{array}$ & $\begin{array}{l}273.07 \pm 10.52 \\
(254.7-296.1) \\
\end{array}$ & $\begin{array}{c}436.86 \pm 3.65 \\
(430.46-444.15) \\
\end{array}$ \\
\hline $\begin{array}{c}\text { August } \\
(2010-2019)\end{array}$ & $\begin{array}{c}24.82 \pm 0.59 \\
(23.95-25.84) \\
\end{array}$ & $\begin{array}{c}35.46 \pm 2.3 \\
(31.81-39.51) \\
\end{array}$ & $\begin{array}{c}310.41 \pm 198 \\
(57.49-741.27) \\
\end{array}$ & $\begin{array}{c}1.83 \pm 0.17 \\
(1.67-2.15)\end{array}$ & $\begin{array}{c}18.04 \pm 1.76 \\
(14.5-19.96)\end{array}$ & $\begin{array}{c}0.32 \pm 0.05 \\
(0.23-0.39)\end{array}$ & $\begin{array}{c}261.09 \pm 13.48 \\
(229.54-281.76)\end{array}$ & $\begin{array}{c}427.21 \pm 4.01 \\
(420.36-434.18)\end{array}$ \\
\hline $\begin{array}{l}\text { September } \\
(2010-2019)\end{array}$ & $\begin{array}{c}21.76 \pm 0.75 \\
(20.76-23.29)\end{array}$ & $\begin{array}{c}34.28 \pm 2.27 \\
(31.27-37.65)\end{array}$ & $\begin{array}{l}144.67 \pm 128.34 \\
(35.44-413.59)\end{array}$ & $\begin{array}{c}1.63 \pm 0.16 \\
(1.37-1.84)\end{array}$ & $\begin{array}{c}14.17 \pm 2.32 \\
(9.66-16.62)\end{array}$ & $\begin{array}{c}0.3 \pm 0.06 \\
(0.22-0.36)\end{array}$ & $\begin{array}{c}240.94 \pm 12.69 \\
(214.93-256.23)\end{array}$ & $\begin{array}{c}397.08 \pm 8.21 \\
(384.37-411.53)\end{array}$ \\
\hline $\begin{array}{c}\text { October } \\
(2010-2019)\end{array}$ & $\begin{array}{c}16.28 \pm 0.67 \\
(15.41-17.55)\end{array}$ & $\begin{array}{c}31.32 \pm 2.14 \\
(28.54-34.8)\end{array}$ & $\begin{array}{l}26.71 \pm 22.77 \\
(0.03-58.86)\end{array}$ & $\begin{array}{c}1.88 \pm 0.15 \\
(1.66-2.07)\end{array}$ & $\begin{array}{c}7.58 \pm 1.98 \\
(4.76-11)\end{array}$ & $\begin{array}{l}0.23 \pm 0.06 \\
(0.15-0.3)\end{array}$ & $\begin{array}{c}208.42 \pm 6.36 \\
(199.84-217.49)\end{array}$ & $\begin{array}{c}345.61 \pm 6.99 \\
(336.76-358.26)\end{array}$ \\
\hline $\begin{array}{l}\text { November } \\
(2010-2019)\end{array}$ & $\begin{array}{l}11.26 \pm 0.52 \\
(10.46-12)\end{array}$ & $\begin{array}{c}25.01 \pm 2.14 \\
(20.85-28.08)\end{array}$ & $\begin{array}{l}17.43 \pm 25.19 \\
(0.05-82.33)\end{array}$ & $\begin{array}{c}2.49 \pm 0.21 \\
(2.18-2.86)\end{array}$ & $\begin{array}{c}4.68 \pm 1.08 \\
(3.06-6.75)\end{array}$ & $\begin{array}{c}0.21 \pm 0.06 \\
(0.15-0.31)\end{array}$ & $\begin{array}{c}154.49 \pm 13.02 \\
(122.82-167.86)\end{array}$ & $\begin{array}{c}307.63 \pm 7.75 \\
(296.51-323.29)\end{array}$ \\
\hline $\begin{array}{l}\text { December } \\
(2010-2019)\end{array}$ & $\begin{array}{c}6.79 \pm 0.99 \\
(5.65-8.63)\end{array}$ & $\begin{array}{c}20.34 \pm 2.06 \\
(16.7-24.55)\end{array}$ & $\begin{array}{l}13.85 \pm 16.82 \\
(0.01-48.49)\end{array}$ & $\begin{array}{c}2.6 \pm 0.24 \\
(2.28-2.93)\end{array}$ & $\begin{array}{c}3.4 \pm 0.89 \\
(2.08-4.89)\end{array}$ & $\begin{array}{c}0.2 \pm 0.05 \\
(0.14-0.31)\end{array}$ & $\begin{array}{c}135.96 \pm 6.53 \\
(121.15-144.45)\end{array}$ & $\begin{array}{c}280.97 \pm 6.64 \\
(268.85-290.74)\end{array}$ \\
\hline
\end{tabular}

Source: The climate data about precipitation, maximum and minimum temperature, specific humidity, soil moisture, wind speed, and downward short and longwave radiations $(2010-2019=10$ years) of the study area (Jhelum) was acquired from United States National Centers for Environmental Prediction (US-NCEP) Climate Forecast System Reanalysis (CFSR) by using climate engine (https://app.climateengine.org/). The data source was CFSv2 $19200 \mathrm{~m}$ (1/5-deg) daily reanalysis dataset (NOAA) 
Table A2. Detailed attributes of the floristic elements of Jhelum district, Punjab, Pakistan

\begin{tabular}{|c|c|c|c|c|c|c|c|}
\hline Family & No. & Species & V/No. & Local name & Habit* & Micro-habitats** & Phenology \\
\hline \multicolumn{8}{|c|}{ Pteridophytes and their related species } \\
\hline 1. Pteridaceae & 1 & Adiantum capillus-veneris $\mathrm{L}$. & $621 / \mathrm{MM} / / 2020$ & Sarhaj & $\mathrm{H}$ & WL & August-September \\
\hline \multicolumn{8}{|c|}{ Gymnosperms } \\
\hline 2. Ephedraceae & 2 & Ephedra ciliata Fisch. \& C.A.Mey. & $880 / \mathrm{MM} / / 2020$ & Phog & $\mathrm{S}$ & $\mathrm{DL}, \mathrm{FO}, \mathrm{GR}, \mathrm{HS}, \mathrm{RS}, \mathrm{SP}, \mathrm{SL}, \mathrm{WP}$ & March-April \\
\hline \multicolumn{8}{|c|}{ Angiosperms (Monocots) } \\
\hline \multirow{2}{*}{ 3. Araceae } & 3 & Colocasia esculenta (L.) Schott & 897/MM//2020 & Arvi & $\mathrm{H}$ & $\mathrm{AL}, \mathrm{HG}$ & June-July \\
\hline & 4 & Pistia stratiotes $\mathrm{L}$. & $515 / \mathrm{MM} / / 2020$ & Water Cabbage & $\mathrm{H}$ & WL & March-April \\
\hline 4. Arecaceae & 5 & Phoenix dactylifera $\mathrm{L}$. & 501/MM//2020 & Khajoor & $\mathrm{T}$ & AL,DL,GL,RS & February-March \\
\hline 5. Asparagaceae & 6 & Agave americana $\mathrm{L}$. & 675/MM//2020 & Desi kwargandal & $\mathrm{S}$ & AL,DL,FO,GL,GR,RS,SP,WP & August-September \\
\hline 6. Cannaceae & 7 & Canna indica $\mathrm{L}$. & $867 / \mathrm{MM} / / 2020$ & Ratta phool & $\mathrm{H}$ & HG & March-April \\
\hline 7. Commelinaceae & 8 & Commelina benghalensis $\mathrm{L}$. & 795/MM//2020 & Kani & $\mathrm{H}$ & FO,GL,HS,RS,SL,SH,WP,WL & March-April \\
\hline \multirow{4}{*}{ 8. Cyperaceae } & 9 & Cyperus difformis $\mathrm{L}$. & 776/MM//2020 & Chota dheela & $\mathrm{H}$ & $\mathrm{AL}, \mathrm{FO}, \mathrm{GL}, \mathrm{GR}, \mathrm{HS}, \mathrm{RS}, \mathrm{SL}, \mathrm{SH}, \mathrm{WP}, \mathrm{WL}$ & August-September \\
\hline & 10 & Cyperus iria $\mathrm{L}$. & 573/MM//2020 & Murak ghaa & $\mathrm{H}$ & AL,FO,GL,GR,HS,RS,SP,SL,SH,WP,WL & August-September \\
\hline & 11 & Cyperus niveus Retz. & $815 / \mathrm{MM} / / 2020$ & Chita dheela & $\mathrm{H}$ & AL,FO,GL,GR,HS,RS,SL,SH,WP,WL & August-September \\
\hline & 12 & Cyperus rotundus $\mathrm{L}$. & 663/MM//2020 & Murak & $\mathrm{H}$ & AL,FO,GL,HS,RS,SL,SH,WP,WL & August-September \\
\hline 9. Juncaceae & 13 & Juncus articulatus $\mathrm{L}$. & 546/MM//2020 & Dheela & $\mathrm{H}$ & FO,GL,HS,WP,WL & August-September \\
\hline \multirow{14}{*}{ 10. Poaceae } & 14 & Apluda mutica L. & $668 / \mathrm{MM} / / 2020$ & Tachuli & $\mathrm{G}$ & AL,DL,FO,GL,GR,RS,SP,WP & August-September \\
\hline & 15 & Aristida abnormis Chiov. & $810 / \mathrm{MM} / / 2020$ & Bara Lumb & G & DL,GL,SP,SH,WP & August-September \\
\hline & 16 & Aristida adscensionis $\mathrm{L}$. & 608/MM//2020 & Chitta Lumb & G & DL,GL,SP,SH,WP & August-September \\
\hline & 17 & Aristida mutabilis Trin. \& Rupr. & $562 / \mathrm{MM} / / 2020$ & Lumb & $\mathrm{G}$ & DL,GL,GR,SP,SH,WP & August-September \\
\hline & 18 & Arundo donax $\mathrm{L}$ & $875 / \mathrm{MM} / / 2020$ & Naru ghaa & G & GL,RS,WP & August-September \\
\hline & 19 & Avena fatua $\mathrm{L}$. & 653/MM//2020 & Jai & G & AL,DL,GL,RS,SP,WP & March-April \\
\hline & 20 & Bothriochloa bladhii (Retz.) S.T.Blake & 696/MM//2020 & Palwan ghaa & $\mathrm{G}$ & AL,GL,HS,RS,SH,WP,WL & August-September \\
\hline & 21 & $\begin{array}{c}\text { Brachiaria deflexa (Schumach.) C.E.Hubb. ex } \\
\text { Robyns }\end{array}$ & $632 / \mathrm{MM} / / 2020$ & Moti ghaa & G & AL,GL,HG,RS,SH,WP,WL & August-September \\
\hline & 22 & Brachiaria distachya (L.) Stapf & $622 / \mathrm{MM} / / 2020$ & Seer ghaa & $\mathrm{G}$ & AL,GL,HS,RS,SH,WP,WL & August-September \\
\hline & 23 & Brachiaria ramosa $($ L.) Stapf & $820 / \mathrm{MM} / / 2020$ & Chota kmadi & G & AL,FO,GL,GR,HS,RS,SH,WP,WL & August-September \\
\hline & 24 & Brachiaria reptans (L.) C.A.Gardner \& C.E.Hubb. & $654 / \mathrm{MM} / / 2020$ & Para ghaa & $\mathrm{G}$ & AL,FO,GL,GR,RS,SH,WP,WL & August-September \\
\hline & 25 & Cenchrus biflorus Roxb. & 692/MM//2020 & Chita Dhaman & G & AL,DL,FO,GL,GR,RS,SP,WP & August-September \\
\hline & 26 & Cenchrus ciliaris $\mathrm{L}$. & 734/MM//2020 & Kala Dhaman & G & DL,FO,GL,RS,SP,WP & August-September \\
\hline & 27 & Cenchrus pennisetiformis Steud. & $870 / \mathrm{MM} / / 2020$ & Kali Dhamani & G & DL,FO,GL,GR,RS,SP & August-September \\
\hline
\end{tabular}




\begin{tabular}{|c|c|c|c|c|c|c|c|}
\hline Family & No. & Species & V/No. & Local name & Habit* & Micro-habitats** & Phenology \\
\hline & 28 & Cenchrus setiger Vahl & 704/MM//2020 & Kala Dhamani & $\mathrm{G}$ & DL,FO,GL,RS,SP,WP & August-September \\
\hline & 29 & Chrysopogon serrulatus Trin. & $586 / \mathrm{MM} / / 2020$ & Jangli jai & $\mathrm{G}$ & DL,FO,GL,RS,SP,WP & August-September \\
\hline & 30 & Chrysopogon aucheri (Boiss.) Stapf & $528 / \mathrm{MM} / / 2020$ & Chitta Dhaman & G & DL,FO,GL,HS,RS,SP,WP & August-September \\
\hline & 31 & Cymbopogon jwarancusa (Jones) Schult. & $839 / \mathrm{MM} / / 2020$ & Lamb ghaa & G & DL,GR,RS,SP,WP & August-September \\
\hline & 32 & Cynodon dactylon (L.) Pers. & $660 / \mathrm{MM} / / 2020$ & Khabbal ghaa & G & $\begin{array}{c}\mathrm{AL}, \mathrm{DL}, \mathrm{FO}, \mathrm{GL}, \mathrm{GR}, \mathrm{HS}, \mathrm{HG}, \mathrm{MS}, \mathrm{RS}, \mathrm{SP}, \mathrm{SL}, \mathrm{SH}, \mathrm{WP}, \\
\text { WL }\end{array}$ & August-September \\
\hline & 33 & Dactyloctenium aegyptium (L.) Willd. & $559 / \mathrm{MM} / / 2020$ & Khar Madana & G & \begin{tabular}{|l|} 
AL,DL,GL,GR,RS,SP,SL,SH,WP,WL \\
\end{tabular} & August-September \\
\hline & 34 & Desmostachya bipinnata (L.) Stapf & 735/MM//2020 & Khusa Dab & $\mathrm{G}$ & DL,GL,GR,SP,WP & August-September \\
\hline & 35 & Dichanthium annulatum (Forssk.) Stapf & $845 / \mathrm{MM} / / 2020$ & Murgha ghaa & G & AL,FO,GL,GR,HS,HG,RS,SL,SH,WP,WL & August-September \\
\hline & 36 & Digitaria nodosa Parl. & $661 / \mathrm{MM} / / 2020$ & Chota ghaa & G & AL,FO,GL,HS,HG,RS,SH,WP,WL & August-September \\
\hline & 37 & Digitaria sanguinalis (L.) Scop. & $538 / \mathrm{MM} / / 2020$ & Toota ghaa & $\mathrm{G}$ & AL,FO,GL,RS,SL,SH,WP,WL & August-September \\
\hline & 38 & Echinochloa colona (L.) Link & $614 / \mathrm{MM} / / 2020$ & Jungli chawly & G & AL,FO,GL,HS,HG,RS,SL,SH,WP,WL & August-September \\
\hline & 39 & Echinochloa crus-galli (L.) P.Beauv. & 731/MM//2020 & Sanwari & G & AL,FO,GL,GR,HS,HG,RS,SL,SH,WP,WL & August-September \\
\hline & 40 & Echinochloa stagnina (Retz.) P.Beauv. & $671 / \mathrm{MM} / / 2020$ & Chawly ghaa & G & $\begin{array}{l}\text { FO,GL,HS,RS,SH,WP,WL } \\
\end{array}$ & August-September \\
\hline & 41 & Eleusine indica (L.) Gaertn. & $822 / \mathrm{MM} / / 2020$ & Nika mdhana & G & AL,FO,GL,HS,RS,SH,WP,WL & August-September \\
\hline & 42 & Eragrostis cilianensis (All.) Janch. & $889 / \mathrm{MM} / / 2020$ & Chitti pholi ghaa & G & FO,GL,HS,RS,SL,SH,WP,WL & August-September \\
\hline & 43 & Eragrostis ciliaris (L.) R.Br. & 789/MM//2020 & Makni ghaa & G & AL,FO,GL,HS,SL,SH,WP,WL & August-September \\
\hline & 44 & Hordeum vulgare $\mathrm{L}$. & $858 / \mathrm{MM} / / 2020$ & Jao & G & AL,DL,RS & February-March \\
\hline & 45 & Imperata cylindrica (L.) Raeusch. & 775/MM//2020 & Baggi sari & G & WL & August-September \\
\hline & 46 & Ochthochloa compressa (Forssk.) Hilu & $529 / \mathrm{MM} / / 2020$ & Tara ghaa & G & DL,HS,RS,SP & August-September \\
\hline & 47 & Oryza sativa $\mathrm{L}$ & $804 / \mathrm{MM} / / 2020$ & Monji, Chawal & G & $\mathrm{AL}, \mathrm{WL}$ & September-October \\
\hline & 48 & Panicum antidotale Retz. & 508/MM//2020 & Bara chawala & G & HS,RS,WL & August-September \\
\hline & 49 & Panicum maximum Jacq. & $524 / \mathrm{MM} / / 2020$ & Bansi ghaa & G & GL,RS,SL,WP,WL & August-September \\
\hline & 50 & Panicum repens $\mathrm{L}$. & 771/MM//2020 & Moti khabal & G & AL,GL,GR,HS,RS,WP,WL & August-September \\
\hline & 51 & Panicum turgidum Forssk. & $807 / \mathrm{MM} / / 2020$ & Garam & G & DL,GL & August-September \\
\hline & 52 & Pennisetum divisum (Forssk. ex J.F.Gmel.) Henrard & 637/MM//2020 & Desi Garam & G & DL,GL & August-September \\
\hline & 53 & Pennisetum orientale Rich. & 541/MM//2020 & Chita ghaa & G & $\mathrm{AL}, \mathrm{GL}, \mathrm{HS}, \mathrm{RS}, \mathrm{WL}$ & August-September \\
\hline & 54 & Pennisetum glaucum (L.) R.Br. & $852 / \mathrm{MM} / / 2020$ & Bajra & G & AL,DL & June-July \\
\hline & 55 & Phalaris minor Retz. & 784/MM//2020 & Dumbi sitti & G & $\mathrm{AL}, \mathrm{GL}, \mathrm{RS}, \mathrm{WP}, \mathrm{WL}$ & March-April \\
\hline & 56 & Phragmites karka (Retz.) Trin. ex Steud. & $540 / \mathrm{MM} / / 2020$ & Narru & G & $\mathrm{RS}, \mathrm{WL}$ & August-September \\
\hline & 57 & Роа аппиа $\mathrm{L}$. & $652 / \mathrm{MM} / / 2020$ & Jangli Jai & G & $\mathrm{AL}, \mathrm{HS}, \mathrm{RS}, \mathrm{WP}, \mathrm{WL}$ & March-April \\
\hline & 58 & Poa pratensis $\mathrm{L}$. & 557/MM//2020 & Sanwak & $\mathrm{G}$ & AL,GL,HS,WP,WL & August-September \\
\hline & 59 & Polypogon fugax Nees ex Steud. & $895 / \mathrm{MM} / / 2020$ & Daddi ghaa & G & AL,GL,GR,HS,RS,SH,WP,WL & August-September \\
\hline
\end{tabular}

APPLIED ECOLOGY AND ENVIRONMENTAL RESEARCH 19(5):3343-3376.

http://www.aloki.hu • ISSN 15891623 (Print) • ISSN 17850037 (Online)

DOI: http://dx.doi.org/10.15666/aeer/1905_33433376

○ 2021, ALÖKI Kft., Budapest, Hungary 


\begin{tabular}{|c|c|c|c|c|c|c|c|}
\hline Family & No. & Species & V/No. & Local name & Habit* & Micro-habitats ${ }^{* *}$ & Phenology \\
\hline & 60 & Saccharum bengalense Retz. & $582 / \mathrm{MM} / / 2020$ & Kana, Sarkanda & $\mathrm{G}$ & FO,GL,GR,HS,RS,SP,SL,WP,WL & August-September \\
\hline & 61 & Saccharum spontaneum $\mathrm{L}$. & $626 / \mathrm{MM} / / 2020$ & Kana & $\mathrm{G}$ & DL,FO,GL,GR,HS,RS,SP,SL,WP,WL & August-September \\
\hline & 62 & Saccharum officinarum $\mathrm{L}$. & $558 / \mathrm{MM} / / 2020$ & Ganna phool & $\mathrm{G}$ & AL,WL & October-November \\
\hline & 63 & Setaria intermedia Roem. \& Schult. & 710/MM//2020 & Choti Chawly & G & $\mathrm{AL}, \mathrm{HS}, \mathrm{RS}, \mathrm{SH}, \mathrm{WP}, \mathrm{WL}$ & August-September \\
\hline & 64 & Setaria italica (L.) P.Beauv. & $824 / \mathrm{MM} / / 2020$ & Kangni ghaa & $\mathrm{G}$ & AL,GL,GR,WP,WL & August-September \\
\hline & 65 & Setaria pumila (Poir.) Roem. \& Schult. & $651 / \mathrm{MM} / / 2020$ & Ban kangni & $\mathrm{G}$ & $\mathrm{AL}, \mathrm{FO}, \mathrm{GL}, \mathrm{RS}, \mathrm{WL}$ & August-September \\
\hline & 66 & Setaria verticillata (L.) P.Beauv. & $898 / \mathrm{MM} / / 2020$ & Bajra ghaa & $\mathrm{G}$ & AL,DL,GL,GR,RS,SH,WP,WL & August-September \\
\hline & 67 & Setaria viridis (L.) P.Beauv. & $854 / \mathrm{MM} / / 2020$ & Lumba Kangni ghaa & $\mathrm{G}$ & AL,DL,GL,GR,RS,WP,WL & August-September \\
\hline & 68 & Sorghum bicolor $($ L.) Moench & $601 / \mathrm{MM} / / 2020$ & Jowar, milo & $\mathrm{G}$ & $\mathrm{AL}, \mathrm{GL}, \mathrm{RS}, \mathrm{WP}, \mathrm{WL}$ & June-July \\
\hline & 69 & Sorghum halepense (L.) Pers. & $548 / \mathrm{MM} / / 2020$ & Kmadi ghaa, Baru & $\mathrm{G}$ & $\mathrm{AL}, \mathrm{GL}, \mathrm{HS}, \mathrm{RS}, \mathrm{WL}$ & August-September \\
\hline & 70 & Stipagrostis plumosa Munro ex T.Anderson & $657 / \mathrm{MM} / / 2020$ & Bhalu ghaa & $\mathrm{G}$ & $\mathrm{AL}, \mathrm{GL}, \mathrm{HS}, \mathrm{WP}, \mathrm{WL}$ & August-September \\
\hline & 71 & Triticum aestivum $\mathrm{L}$. & $876 / \mathrm{MM} / / 2020$ & Kanak, Gandum & $\mathrm{G}$ & $\mathrm{AL}, \mathrm{HS}, \mathrm{SP}$ & February-March \\
\hline & 72 & Zea mays $\mathrm{L}$. & $803 / \mathrm{MM} / / 2020$ & Makai & $\mathrm{G}$ & AL,GL,HS,RS,WL & June-July \\
\hline 11 Tynhocen & 73 & Typha domingensis Pers. & $506 / \mathrm{MM} / / 2020$ & Konder & $\mathrm{H}$ & WL & October-November \\
\hline 11. Typhaceae & 74 & Typha elephantina Roxb. & $884 / \mathrm{MM} / / 2020$ & Kondar & $\mathrm{H}$ & WL & August-September \\
\hline & 75 & Aloe vera (L.) Burm.f. & $894 / \mathrm{MM} / / 2020$ & Kawar gandal & $\mathrm{H}$ & AL,DL,FO,GR,HG & August-September \\
\hline 12. Xanthorrhoeaceae & 76 & Asphodelus tenuifolius Cav. & $585 / \mathrm{MM} / / 2020$ & Piazi & $\mathrm{H}$ & AL,FO,GL,GR,HS,RS,SP,SL,SH,WP,WL & February-March \\
\hline \multicolumn{8}{|c|}{ Angiosperms (Dicots) } \\
\hline \multirow{3}{*}{ 13. Acanthaceae } & 77 & Dicliptera bupleuroides Nees & $881 / \mathrm{MM} / / 2020$ & Rewari & $\mathrm{H}$ & AL,DL,FO,GL,GR,RS,SH,WP & March-April \\
\hline & 78 & Dicliptera verticillata (Forssk.) C.Chr. & $590 / \mathrm{MM} / / 2020$ & Jamni booti & $\mathrm{H}$ & DL,FO,GR,HS,RS,SP,SL,SH,WP & February-April \\
\hline & 79 & Justicia adhatoda $\mathrm{L}$ & $574 / \mathrm{MM} / / 2020$ & Baikr & $\mathrm{S}$ & DL,FO,GL,GR,HS,MS,RS,SL & February-March \\
\hline \multirow{3}{*}{ 14. Aizoaceae } & 80 & Trianthema portulacastrum $\mathrm{L}$. & $525 / \mathrm{MM} / / 2020$ & Jangli Sanwak & $\mathrm{H}$ & AL,DL,FO,GL,HS,RS,SH,WP,WL & June-July \\
\hline & 81 & Trianthema triquetra Rottler \& Willd. & $570 / \mathrm{MM} / / 2020$ & Choti alwati & $\mathrm{H}$ & DL,FO,GL,GR,HS,MS,SP,SL,WP & June-July \\
\hline & 82 & Zaleya pentandra (L.) C.Jeffrey & $715 / \mathrm{MM} / / 2020$ & Ratti Hazar dani & $\mathrm{H}$ & AL,FO,GL,GR,RS,SL,SH,WL & August-September \\
\hline \multirow{8}{*}{ 15. Amaranthaceae } & 83 & Achyranthes aspera $\mathrm{L}$. & $802 / \mathrm{MM} / / 2020$ & Puth kanda & $\mathrm{H}$ & AL,DL,FO,GL,GR,RS,WP,WL & August-September \\
\hline & 84 & Achyranthes bidentata Blume & $512 / \mathrm{MM} / / 2020$ & Puth kanda & $\mathrm{H}$ & AL,DL,FO,GL,GR,RS & August-September \\
\hline & 85 & Aerva javanica (Burm.f.) Juss. ex Schult. & $544 / \mathrm{MM} / / 2020$ & Niki boi & $\mathrm{H}$ & DL,FO,GR,HS,SP,SL,WP & February-April \\
\hline & 86 & Aerva lanata $($ L.) Juss. & 688/MM//2020 & Boi & $\mathrm{H}$ & DL,FO,GR,HS,SP,SL,WP & May-July \\
\hline & 87 & Alternanthera paronychioides A.St.-Hil. & $724 / \mathrm{MM} / / 2020$ & Chitti pholi & $\mathrm{H}$ & DL,FO,GR,HS,MS,SP & August-September \\
\hline & 88 & Alternanthera pungens Kunth & 706/MM//2020 & Khaki, Bhakrra & $\mathrm{H}$ & FO,GL,HS,RS,SL,SH,WP & March-April \\
\hline & 89 & Alternanthera sessilis (L.) R.Br. ex DC. & $509 / \mathrm{MM} / / 2020$ & Poni booti & $\mathrm{H}$ & FO,GL,HS,SL,SH,WP,WL & September-October \\
\hline & 90 & Amaranthus deflexus $\mathrm{L}$. & $542 / \mathrm{MM} / / 2020$ & Jangli Tandla & $\mathrm{H}$ & AL,FO,GL,HS,SH,WP & August-September \\
\hline
\end{tabular}

APPLIED ECOLOGY AND ENVIRONMENTAL RESEARCH 19(5):3343-3376.

http://www.aloki.hu • ISSN 15891623 (Print) • ISSN 17850037 (Online)

DOI: http://dx.doi.org/10.15666/aeer/1905_33433376

๑) 2021, ALÖKI Kft., Budapest, Hungary 


\begin{tabular}{|c|c|c|c|c|c|c|c|}
\hline Family & No. & Species & V/No. & Local name & Habit* & Micro-habitats*** & Phenology \\
\hline & 91 & Amaranthus graecizans L. & $634 / \mathrm{MM} / / 2020$ & Pohli & $\mathrm{H}$ & FO,GL,HS,RS,SL,SH,WP & August-September \\
\hline & 92 & Amaranthus retroflexus $\mathrm{L}$. & $673 / \mathrm{MM} / / 2020$ & Aam bathoo & $\mathrm{H}$ & FO,GL,GR,HS,RS,SL,SH,WP & March-April \\
\hline & 93 & Amaranthus spinosus $\mathrm{L}$. & 787/MM//2020 & Konjel & $\mathrm{H}$ & FO,GL,HS,RS,SH,WP,WL & March-April \\
\hline & 94 & Amaranthus viridis $\mathrm{L}$. & $878 / \mathrm{MM} / / 2020$ & Tandla & $\mathrm{H}$ & AL,GL,HS,RS,SL,SH,WP & August-September \\
\hline & 95 & Atriplex aucheri Moq. & $678 / \mathrm{MM} / / 2020$ & Loni jhari & $\mathrm{S}$ & DL,FO,GL,GR,HS,SL,SH,WP & July-August \\
\hline & 96 & Atriplex dimorphostegia Kar. \& Kir. & 736/MM//2020 & Loni booti & $\mathrm{H}$ & FO,GL,HS,RS,WP,WL & August-September \\
\hline & 97 & Atriplex griffithii Moq. & $551 / \mathrm{MM} / / 2020$ & Lani jhari & $\mathrm{S}$ & DL,FO,GL,GR,HS,RS,SP,SL,SH & May-July \\
\hline & 98 & Bassia hyssopifolia (Pall.) Kuntze & $825 / \mathrm{MM} / / 2020$ & Chotti lani, Retli booti & $\mathrm{H}$ & DL,FO,GL,GR,HS,RS,SH,WP & March-April \\
\hline & 99 & Beta vulgaris L. & $744 / \mathrm{MM} / 2020$ & Chukandar & $\mathrm{H}$ & AL,GL,HG,RS & March-April \\
\hline & 100 & Chenopodium album $\mathrm{L}$. & 748/MM//2020 & Bathoo & $\mathrm{H}$ & AL,FO,GL,GR,HS,RS,SL,SH,WP & March-April \\
\hline & 101 & Chenopodium ficifolium $\mathrm{Sm}$. & $552 / \mathrm{MM} / 2020$ & Jangli Bathoo & $\mathrm{H}$ & DL,FO,GL,GR,HS,RS,SH & March-April \\
\hline & 102 & Chenopodium murale $\mathrm{L}$. & $805 / \mathrm{MM} / / 2020$ & Karwa bathoo & $\mathrm{H}$ & FO,GL,GR,HS,RS,SL & March-April \\
\hline & 103 & Chenородіuт glauсит $\mathrm{L}$. & 887/MM//2020 & Ratta Bathoo & $\mathrm{H}$ & FO,GL,GR,HS,RS,SH,WP & March-April \\
\hline & 104 & Chenopodium vulvaria $\mathrm{L}$. & $611 / \mathrm{MM} / / 2020$ & Chitta bathoo & $\mathrm{H}$ & AL,DL,RS & March-April \\
\hline & 105 & Digera muricata (L.) Mart. & $694 / \mathrm{MM} / / 2020$ & Tandla saag & $\mathrm{H}$ & FO,GL,GR,HS,RS,SH,WP,WL & August-September \\
\hline & 106 & $\begin{array}{c}\text { Dysphania ambrosioides (L.) Mosyakin \& } \\
\text { Clemants }\end{array}$ & $856 / \mathrm{MM} / / 2020$ & Desi Bathoo & $\mathrm{H}$ & AL,DL,FO,GL,GR,HS,RS,SL,SH,WP & August-September \\
\hline & 107 & Spinacia oleracea $\mathrm{L}$. & $823 / \mathrm{MM} / / 2020$ & Pallak & $\mathrm{H}$ & AL,GL,HG & March-April \\
\hline & 108 & Suaeda acuminata (C.A.Mey.) Moq. & $583 / \mathrm{MM} / / 2020$ & Smandri booti & $\mathrm{H}$ & DL,FO,GL,GR,HS,RS,SP,SH & August-September \\
\hline & 109 & Suaeda vermiculata Forssk. ex J.F.Gmel. & 799/MM//2020 & Lani booti & $\mathrm{S}$ & FO,GL,GR,HS,RS,SL,SH,WP & March-April \\
\hline \multirow{2}{*}{ 16. Amaryllidaceae } & 110 & Allium cepa $\mathrm{L}$. & $602 / \mathrm{MM} / / 2020$ & Ganda & $\mathrm{H}$ & RS & March-April \\
\hline & 111 & Allium sativum $\mathrm{L}$. & $684 / \mathrm{MM} / / 2020$ & Thoom & $\mathrm{H}$ & $\mathrm{AL}, \mathrm{GL}, \mathrm{HG}$ & March-April \\
\hline 17. Anacardiaceae & 112 & Mangifera indica $\mathrm{L}$. & $580 / \mathrm{MM} / 2020$ & Aam & $\mathrm{T}$ & AL,GL,HG,RS & May-June \\
\hline 18. Annonaceae & 113 & Polyalthia longifolia (Sonn.) Thwaites & $677 / \mathrm{MM} / / 2020$ & Ulta ashoq & $\mathrm{T}$ & HG,RS & April-June \\
\hline \multirow{4}{*}{ 19. Apiaceae } & 114 & Centella asiatica $(\mathrm{L}$.$) Urb.$ & $893 / \mathrm{MM} / / 2020$ & Chattri & $\mathrm{H}$ & $\mathrm{DL}, \mathrm{GL}, \mathrm{GR}, \mathrm{HS}, \mathrm{SH}, \mathrm{WP}$ & June-August \\
\hline & 115 & Coriandrum sativum $\mathrm{L}$. & $513 / \mathrm{MM} / / 2020$ & Dhaniya & $\mathrm{H}$ & AL,GL,HG,RS & March-April \\
\hline & 116 & Daucus carota $\mathrm{L}$. & 843/MM//2020 & Gajjar & $\mathrm{H}$ & $\mathrm{AL}, \mathrm{GL}, \mathrm{HG}$ & March-April \\
\hline & 117 & Foeniculum vulgare Mill. & $517 / \mathrm{MM} / / 2020$ & Sounf & $\mathrm{H}$ & $\mathrm{AL}, \mathrm{GL}, \mathrm{HG}$ & March-April \\
\hline \multirow{5}{*}{ 20. Apocynaceae } & 118 & Blyttia spiralis (Forssk.) D.V.Field \& J.R.I.Wood & $598 / \mathrm{MM} / / 2020$ & Wal-tara & $\mathrm{H}$ & FO,HS,SH,WP & March-April \\
\hline & 119 & Calotropis procera (Aiton) Dryand. & $640 / \mathrm{MM} / / 2020$ & Ak & $\mathrm{S}$ & DL,FO,GR,HS,RS,SP,WP & March-April \\
\hline & 120 & Calotropis gigantea (L.) Dryand. & $565 / \mathrm{MM} / 2020$ & Bara ak & $\mathrm{S}$ & DL,FO,GR,HS,RS,SP,SH,WP & March-April \\
\hline & 121 & Cascabela thevetia $(\mathrm{L}$.) Lippold & 793/MM//2020 & Peeli kanier & $\mathrm{T}$ & AL,GL,HG,RS & March-April \\
\hline & 122 & Leptadenia pyrotechnica (Forssk.) Decne. & 883/MM//2020 & Khip & $\mathrm{S}$ & DL,FO,GR,HS,RS,SP,WP & September-October \\
\hline
\end{tabular}

APPLIED ECOLOGY AND ENVIRONMENTAL RESEARCH 19(5):3343-3376.

http://www.aloki.hu • ISSN 15891623 (Print) • ISSN 17850037 (Online)

DOI: http://dx.doi.org/10.15666/aeer/1905_33433376

○ 2021, ALÖKI Kft., Budapest, Hungary 


\begin{tabular}{|c|c|c|c|c|c|c|c|}
\hline Family & No. & Species & V/No. & Local name & Habit* & Micro-habitats** & Phenology \\
\hline & 123 & Nerium oleander $\mathrm{L}$. & 658/MM//2020 & Kanair & $\mathrm{S}$ & HG,RS & July-August \\
\hline & 124 & Pentatropis capensis (L. f.) Bullock & 853/MM//2020 & Tara lee & $\mathrm{H}$ & FO,GL,GR,HS,RS,SL,SH,WP & March-April \\
\hline & 125 & Pergularia daemia (Forssk.) Chiov. & 774/MM//2020 & Sapni vail & $\mathrm{H}$ & FO,GR,HS,RS,SH,WP & February-April \\
\hline & 126 & Pergularia tomentosa $\mathrm{L}$. & 606/MM//2020 & Jangli Sapni vail & $\mathrm{H}$ & FO,HS,RS,SH,WP,WL & February-April \\
\hline & 127 & Rhazya stricta Decne. & 672/MM//2020 & Wlayti Ak & $\mathrm{S}$ & DL,FO,GL,GR,HS,RS,SP,SL,SH,WP & August-September \\
\hline & 128 & Tylophora hirsuta Wight & 563/MM//2020 & Panjni jhari & $\mathrm{S}$ & AL,GL,HG,RS & May-July \\
\hline 21. Berberidaceae & 129 & Berberis lycium Royle. & $840 / \mathrm{MM} / / 2020$ & Sumbulu & $\mathrm{T}$ & AL,GL,RS & March-April \\
\hline 22. Bignoniaceae & 130 & Tecoma stans (L.) Juss. ex Kunth & $806 / \mathrm{MM} / / 2020$ & Peeli jhari & $\mathrm{S}$ & HG,RS & August-September \\
\hline \multirow{8}{*}{ 23. Boraginaceae } & 131 & Cordia myxa L. & 535/MM//2020 & Lasura & $\mathrm{T}$ & AL,GL,HG,RS & March-April \\
\hline & 132 & Cordia dichotoma G.Forst. & $518 / \mathrm{MM} / / 2020$ & Lasuree & $\mathrm{T}$ & AL,GL,HG,RS & March-April \\
\hline & 133 & Heliotropium aucheri DC. & 871/MM//2020 & Tara booti & $\mathrm{H}$ & $\mathrm{DL}, \mathrm{FO}, \mathrm{GL}, \mathrm{GR}, \mathrm{HS}, \mathrm{RS}, \mathrm{SP}, \mathrm{SL}$ & March-April \\
\hline & 134 & Heliotropium crispum Desf. & $682 / \mathrm{MM} / / 2020$ & Chitti choli & $\mathrm{H}$ & DL,FO,GR,HS,RS,SP,SL,SH,WP & August-September \\
\hline & 135 & Heliotropium curassavicum $\mathrm{L}$. & 507/MM//2020 & Lani pata & $\mathrm{H}$ & DL,FO,GR,HS,RS,SP,SL,SH,WP & March-April \\
\hline & 136 & Heliotropium europaeum $\mathrm{L}$. & 616/MM//2020 & Uth chaaro, Hathi sundi & $\mathrm{H}$ & DL,FO,GL,GR,HS,RS,SP,SL,SH,WP & August-September \\
\hline & 137 & Heliotropium strigosum Willd. & 756/MM//2020 & Chita koka & $\mathrm{H}$ & DL,FO,GR,RS,SP,SL,SH,WP & March-April \\
\hline & 138 & Heliotropium supinum $\mathrm{L}$. & 533/MM//2020 & Choti boi & $\mathrm{H}$ & DL,FO,GR,HS,RS,SP,SL,WP & March-April \\
\hline \multirow{15}{*}{ 24. Brassicaceae } & 139 & Brassica nigra (L.) K.Koch & 792/MM//2020 & Kala saroon, Kala rayea & $\mathrm{H}$ & $\mathrm{AL}, \mathrm{GL}$ & March-April \\
\hline & 140 & Brassica oleracea $\mathrm{L}$. & 770/MM//2020 & Band ghobi & $\mathrm{H}$ & \begin{tabular}{|c|} 
AL,GL,HG \\
\end{tabular} & February-March \\
\hline & 141 & Brassica deflexa Boiss. & 782/MM//2020 & Peela saroon & $\mathrm{H}$ & $\begin{array}{c}\text { AL,DL,FO,GL,GR,HS,HG,MS,RS,SP,SL,SH,WP, } \\
\text { WL }\end{array}$ & March-April \\
\hline & 142 & Brassica juncea (L.) Czern. & 674/MM//2020 & Peela raya & $\mathrm{H}$ & \begin{tabular}{|c|} 
AL,GL \\
\end{tabular} & March-April \\
\hline & 143 & Brassica napus L. & 629/MM//2020 & Shaljam & $\mathrm{H}$ & AL,GL,HG & February-March \\
\hline & 144 & Brassica rapa $\mathrm{L}$. & 619/MM//2020 & Peeli rayi & $\mathrm{H}$ & AL,GL & February-March \\
\hline & 145 & Brassica tournefortii Gouan & $828 / \mathrm{MM} / / 2020$ & Sirmi & $\mathrm{H}$ & $\mathrm{AL}, \mathrm{GL}$ & February-March \\
\hline & 146 & Capsella bursa-pastoris (L.) Medik. & 760/MM//2020 & Mirch booti & $\mathrm{H}$ & FO,GL,GR,HS,MS,RS,SH,WP,WL & August-September \\
\hline & 147 & Eruca vesicaria (L.) Cav. & 751/MM//2020 & $\begin{array}{c}\text { Tara Meera, Osoon } \\
\text { rayea }\end{array}$ & $\mathrm{H}$ & AL,FO,GL,GR,HS,MS,RS,SL,SH,WP,WL & March-April \\
\hline & 148 & Lepidium apetalum Willd. & $505 / \mathrm{MM} / / 2020$ & Jangli Khoob kalan & $\mathrm{H}$ & FO,GL,HS,MS,SH,WP,WL & July-August \\
\hline & 149 & Lepidium didymum $\mathrm{L}$. & 703/MM//2020 & Chattri booti & $\mathrm{H}$ & AL,FO,GL,GR,HS,MS,SL,SH,WP,WL & March-April \\
\hline & 150 & Lepidium aucheri Boiss. & 873/MM//2020 & Choti Lani & $\mathrm{H}$ & FO,GL,GR,HS,MS,RS,SL,SH,WP,WL & April-May \\
\hline & 151 & Lepidium sativum $\mathrm{L}$. & $813 / \mathrm{MM} / / 2020$ & Bag bhari & $\mathrm{H}$ & HG,RS,SH & March-April \\
\hline & 152 & Malcolmia africana (L.) R.Br. & 780/MM//2020 & Chiti phuli & $\mathrm{H}$ & DL,FO,GL,GR,MS,RS,SH,WP,WL & March-April \\
\hline & 153 & Raphanus raphanistrum $\mathrm{L}$. & 664/MM//2020 & Mongrae & $\mathrm{H}$ & AL,GL,HG & February-April \\
\hline
\end{tabular}

APPLIED ECOLOGY AND ENVIRONMENTAL RESEARCH 19(5):3343-3376.

http://www.aloki.hu • ISSN 15891623 (Print) • ISSN 17850037 (Online)

DOI: http://dx.doi.org/10.15666/aeer/1905_33433376

○ 2021, ALÖKI Kft., Budapest, Hungary 


\begin{tabular}{|c|c|c|c|c|c|c|c|}
\hline Family & No. & Species & V/No. & Local name & Habit* & Micro-habitats** & Phenology \\
\hline & 154 & Sisymbrium irio L. & $750 / \mathrm{MM} / / 2020$ & Peeli Saroon & $\mathrm{H}$ & AL,GL,HS,RS,SH,WP & March-April \\
\hline & 155 & Sisymbrium orientale $\mathrm{L}$. & $826 / \mathrm{MM} / / 2020$ & Jangli Saroon & $\mathrm{H}$ & AL,GL,HS,RS,SH,WP & March-April \\
\hline 25. Cactaceae & 156 & Opuntia dillenii (Ker Gawl.) Haw. & 699/MM//2020 & Chitter thore & $\mathrm{H}$ & DL,HS,SP,SL,SH,WP & March-April \\
\hline 26. Cannabaceae & 157 & Cannabis sativa $\mathrm{L}$ & 669/MM//2020 & Bhang & $\mathrm{H}$ & AL,GL,GR,RS,SH,WP,WL & March-April \\
\hline 27. Capparaceae & 158 & Capparis decidua (Forssk.) Edgew. & $532 / \mathrm{MM} / / 2020$ & Karir & $\mathrm{S}$ & DL,FO,GR,HS,SP & August-September \\
\hline 28. Caricaceae & 159 & Carica papaya $\mathrm{L}$ & 904/MM//2020 & Papeeta & $\mathrm{S}$ & AL,GL,HG & March-April \\
\hline \multirow{4}{*}{ 29. Caryophyllaceae } & 160 & Stellaria media (L.) Vill. & 796/MM//2020 & Chitti booti & $\mathrm{H}$ & AL,FO,GL,HS,MS,RS,SL,SH,WP & March-April \\
\hline & 161 & Stellaria persica Boiss. & $511 / \mathrm{MM} / / 2020$ & Sitara booti & $\mathrm{H}$ & AL,FO,GL,HS,RS,SL,SH,WP & July-August \\
\hline & 162 & Stellaria decumbens Edgew. & $587 / \mathrm{MM} / / 2020$ & Chitti cona & $\mathrm{H}$ & FO & July-August \\
\hline & 163 & Stellaria monosperma Buch.-Ham. ex D. Don & $716 / \mathrm{MM} / / 2020$ & Ghal booti & $\mathrm{H}$ & FO,GL,GR,RS,SL,SH,WP,WL & July-August \\
\hline 30. Cleomaceae & 164 & Cleome viscosa $\mathrm{L}$ & 578/MM//2020 & Zard booti & $\mathrm{H}$ & FO,GL,GR,RS,SH,WP,WL & March-April \\
\hline \multirow{18}{*}{ 31. Compositae } & 165 & Carthamus oxyacantha M.Bieb. & $863 / \mathrm{MM} / / 2020$ & Pholi, Kandiyari & $\mathrm{H}$ & DL,FO,GL,GR,HS,RS,SP,SL,WP & August-September \\
\hline & 166 & Cirsium arvense (L.) Scop. & 761/MM//2020 & Kandiyari & $\mathrm{H}$ & DL,FO,GL,GR,HS,SP,SH,WP & March-April \\
\hline & 167 & Cirsium falconeri (Hook.f.) Petr. & $720 / \mathrm{MM} / / 2020$ & Jhalar Kandiyari & $\mathrm{H}$ & DL,FO,GR,HS,RS,SP,SH,WP & September-October \\
\hline & 168 & Echinops echinatus Roxb. & $566 / \mathrm{MM} / / 2020$ & Ont-ktara & $\mathrm{H}$ & DL,FO,GL,GR,HS,RS,SP,SL,SH & March-April \\
\hline & 169 & Eclipta prostrata $(\mathrm{L}.) \mathrm{L}$. & $847 / \mathrm{MM} / / 2020$ & Bhangra & $\mathrm{H}$ & AL,FO,GL,GR,RS,SH,WP,WL & March-April \\
\hline & 170 & Erigeron aegyptiacus $\mathrm{L}$. & $757 / \mathrm{MM} / / 2020$ & Jangli Genda Phool & $\mathrm{H}$ & AL,FO,GL,GR,RS,SP,SH & September-October \\
\hline & 171 & Erigeron bonariensis L. & $872 / \mathrm{MM} / / 2020$ & Dodi booti & $\mathrm{H}$ & DL,FO,GR,HS,RS,SH,WL & March-April \\
\hline & 172 & Erigeron canadensis $\mathrm{L}$. & $605 / \mathrm{MM} / / 2020$ & Konjel pholi & $\mathrm{H}$ & DL,FO,GL,GR,RS,SH,WL & October-November \\
\hline & 173 & Lactuca serriola $\mathrm{L}$. & $609 / \mathrm{MM} / / 2020$ & Bhatal & $\mathrm{H}$ & AL,FO,GL,GR,HS,RS,SH,WP,WL & March-April \\
\hline & 174 & Launaea nudicaulis (L.) Hook.f. & $861 / \mathrm{MM} / / 2020$ & Dodak, Dudhkal & $\mathrm{H}$ & $\mathrm{AL}, \mathrm{FO}, \mathrm{GL}, \mathrm{GR}, \mathrm{RS}, \mathrm{SH}$ & March-April \\
\hline & 175 & $\begin{array}{c}\text { Launaea procumbens (Roxb.) Ramayya \& } \\
\text { Rajagopal }\end{array}$ & $821 / \mathrm{MM} / / 2020$ & Dodak, Bhathala & $\mathrm{H}$ & AL,FO,GL,GR,RS,SH,WP,WL & March-April \\
\hline & 176 & Parthenium hysterophorus $\mathrm{L}$. & 670/MM//2020 & Koka booti & $\mathrm{H}$ & AL,DL,FO,GL,GR,RS,SH,WP,WL & March-April \\
\hline & 177 & Silybum marianum (L.) Gaertn. & $553 / \mathrm{MM} / / 2020$ & Ount Katara & $\mathrm{H}$ & DL,GL,GR,RS,SL,SH,WP & March-April \\
\hline & 178 & Sonchus arvensis $\mathrm{L}$. & $623 / \mathrm{MM} / / 2020$ & Peeli Bhattal & $\mathrm{H}$ & AL,GL,GR,HS,RS,SL,SH,WP & March-April \\
\hline & 179 & Sonchus asper $($ L.) Hill & $666 / \mathrm{MM} / / 2020$ & Bhattal & $\mathrm{H}$ & DL,FO,GL,HS,RS,SL,SH & March-April \\
\hline & 180 & Sonchus oleraceus (L.) L. & 713/MM//2020 & Peeli dodhak & $\mathrm{H}$ & $\mathrm{AL}, \mathrm{FO}, \mathrm{GR}, \mathrm{RS}, \mathrm{SH}$ & March-April \\
\hline & 181 & Tagetes erecta $\mathrm{L}$. & $830 / \mathrm{MM} / / 2020$ & Peela Genda & $\mathrm{H}$ & $\begin{array}{c}\text { HG,RS,SH } \\
\end{array}$ & July-September \\
\hline & 182 & Xanthium strumarium L. & $764 / \mathrm{MM} / / 2020$ & Puth kanda & $\mathrm{H}$ & AL,DL,FO,GL,GR,HS,RS,SH,WP,WL & March-April \\
\hline \multirow{3}{*}{ 32. Convolvulaceae } & 183 & Convolvulus arvensis $\mathrm{L}$. & $728 / \mathrm{MM} / / 2020$ & Lelli & $\mathrm{H}$ & AL,FO,GL,GR,RS,SH,WL & March-April \\
\hline & 184 & Convolvulus prostratus Forssk. & 785/MM//2020 & Lehi, Vanvaihre & $\mathrm{H}$ & AL,FO,GL,GR,RS,SH,WL & February-April \\
\hline & 185 & Convolvulus lineatus $\mathrm{L}$. & $888 / \mathrm{MM} / / 2020$ & Waja vail & $\mathrm{H}$ & AL,FO,GL,GR,RS,SP,SH,WL & March-April \\
\hline
\end{tabular}

APPLIED ECOLOGY AND ENVIRONMENTAL RESEARCH 19(5):3343-3376.

http://www.aloki.hu • ISSN 15891623 (Print) • ISSN 17850037 (Online)

DOI: http://dx.doi.org/10.15666/aeer/1905_33433376

( 2021 , ALÖKI Kft., Budapest, Hungary 


\begin{tabular}{|c|c|c|c|c|c|c|c|}
\hline Family & No. & Species & V/No. & Local name & Habit* & Micro-habitats $^{* *}$ & Phenology \\
\hline & 186 & Cuscuta reflexa Roxb. & 811/MM//2020 & Ashk bail, Ambar bail & $\mathrm{H}$ & AL,DL,FO,GR,HS,RS,SL,SH,WP,WL & December-January \\
\hline & 187 & Ipomoea alba $\mathrm{L}$. & 534/MM//2020 & Sawer pholi & $\mathrm{H}$ & AL,GL,HG,RS,SH,WL & March-April \\
\hline & 188 & Ipomoea carnea Jacq. & 729/MM//2020 & Gull e abbasi & $\mathrm{S}$ & $\mathrm{AL}, \mathrm{RS}, \mathrm{WL}$ & August-September \\
\hline & 189 & Ipomoea pes-tigridis $\mathrm{L}$. & 903/MM//2020 & Chitti chatri & $\mathrm{H}$ & AL,DL,GL,GR,HS,RS,SH,WP,WL & August-September \\
\hline & 190 & Ipomoea aquatica Forssk. & $896 / \mathrm{MM} / / 2020$ & Jungli vail & $\mathrm{H}$ & $\mathrm{AL}, \mathrm{FO}, \mathrm{GL}, \mathrm{GR}, \mathrm{RS}, \mathrm{SH}, \mathrm{WL}$ & February-April \\
\hline & 191 & Ipomoea cairica $(\mathrm{L}$.$) Sweet$ & 604/MM//2020 & Jungli lehli & $\mathrm{H}$ & AL,FO,GL,GR,HS,RS,SL,SH,WP,WL & July-August \\
\hline \multirow{12}{*}{ 33. Cucurbitaceae } & 192 & Benincasa hispida (Thunb.) Cogn. & 730/MM//2020 & Bari Khakhri & $\mathrm{H}$ & AL,GL,HG & June-July \\
\hline & 193 & Citrullus colocynthis (L.) Schrad. & 638/MM//2020 & Tumma & $\mathrm{H}$ & AL,DL,FO,GL,GR,HS,RS,SP,SL,SH,WP & May-June \\
\hline & 194 & Citrullus lanatus (Thunb.) Matsum. \& Nakai & $755 / \mathrm{MM} / / 2020$ & Dwana, Turbooz & $\mathrm{H}$ & AL,GL,HG & July-August \\
\hline & 195 & Cucumis sativus $\mathrm{L}$. & $635 / \mathrm{MM} / / 2020$ & Khera & $\mathrm{H}$ & AL,GL,HG & June-July \\
\hline & 196 & Cucumis melo $\mathrm{L}$. & $527 / \mathrm{MM} / / 2020$ & Khakhri & $\mathrm{H}$ & $\mathrm{AL}, \mathrm{GL}, \mathrm{HG}$ & June-July \\
\hline & 197 & Cucurbita moschata Duchesne & 718/MM//2020 & Paitha & $\mathrm{H}$ & AL,GL,HG & June-July \\
\hline & 198 & Cucurbita maxima Duchesne & 702/MM//2020 & Ghea & $\mathrm{H}$ & $\mathrm{AL}, \mathrm{GL}, \mathrm{HG}$ & June-July \\
\hline & 199 & Cucurbita pepo L. & 709/MM//2020 & Kaddu & $\mathrm{H}$ & AL,GL,HG & June-July \\
\hline & 200 & Luffa acutangula (L.) Roxb. & $624 / \mathrm{MM} / / 2020$ & Kali Toori & $\mathrm{H}$ & AL,GL,HG & June-July \\
\hline & 201 & Luffa cylindrica (L.) M.Roem. & $522 / \mathrm{MM} / / 2020$ & Ghea toori & $\mathrm{H}$ & AL,GL,HG & June-July \\
\hline & 202 & Momordica balsamina $\mathrm{L}$. & 712/MM//2020 & Jangli kraila & $\mathrm{H}$ & AL,GL,HG & May-June \\
\hline & 203 & Praecitrullus fistulosus (Stocks) Pangalo & $809 / \mathrm{MM} / / 2020$ & Tinda & $\mathrm{H}$ & AL,GL,HG & June-July \\
\hline \multirow{14}{*}{ 34. Euphorbiaceae } & 204 & Chrozophora tinctoria (L.) A.Juss. & $850 / \mathrm{MM} / / 2020$ & Chitti Boi & $\mathrm{H}$ & DL,FO,GR,HS,RS,SP,SL,WP & May-June \\
\hline & 205 & $\begin{array}{l}\text { Chrozophora oblongifolia (Delile) A.Juss. ex } \\
\text { Spreng. }\end{array}$ & 781/MM//2020 & Khuri & $\mathrm{H}$ & DL,FO,GR,HS,SP,WP & August-September \\
\hline & 206 & Chrozophora plicata (Vahl) A.Juss. ex Spreng. & 656/MM//2020 & Chitri booti & $\mathrm{H}$ & DL,FO,GR,HS,RS,SP,WP & August-September \\
\hline & 207 & Chrozophora sabulosa Kar. \& Kir. & $687 / \mathrm{MM} / / 2020$ & Giri booti & $\mathrm{H}$ & DL,FO,GL,GR,HS,RS,SP,WP & August-September \\
\hline & 208 & Croton bonplandianus Baill. & 762/MM//2020 & Kala bhangra & $\mathrm{H}$ & FO,GL,GR,HS,RS,SH,WP,WL & March-April \\
\hline & 209 & Euphorbia cyathophora Murray & $848 / \mathrm{MM} / / 2020$ & Pathar chat & $\mathrm{S}$ & HG,RS,SH & March-April \\
\hline & 210 & Euphorbia helioscopia $\mathrm{L}$. & $892 / \mathrm{MM} / / 2020$ & Choti chattri & $\mathrm{H}$ & AL,FO,GL,GR,RS,SH,WP,WL & March-April \\
\hline & 211 & Euphorbia hirta L. & $801 / \mathrm{MM} / / 2020$ & Lal dhudi & $\mathrm{H}$ & AL,FO,GL,GR,HS,HG,MS,RS,SL,SH,WP,WL & March-April \\
\hline & 212 & Euphorbia indica Lam. & $837 / \mathrm{MM} / / 2020$ & Dudhi kalan & $\mathrm{H}$ & $\mathrm{AL}, \mathrm{FO}, \mathrm{GL}, \mathrm{GR}, \mathrm{HS}, \mathrm{RS}, \mathrm{WP}, \mathrm{WL}$ & March-April \\
\hline & 213 & Euphorbia prostrata Aiton & 648/MM//2020 & Choti it-sit & $\mathrm{H}$ & AL,DL,GL,GR,HS,HG,RS,SH,WP & June-July \\
\hline & 214 & Euphorbia thymifolia $\mathrm{L}$. & $819 / \mathrm{MM} / / 2020$ & It-sit & $\mathrm{H}$ & AL,DL,FO,GL,GR,HS,HG,RS,SH,WP & June-July \\
\hline & 215 & Euphorbia densa Schrenk & $584 / \mathrm{MM} / / 2020$ & Dhodak & $\mathrm{H}$ & AL,DL,FO,GL,GR,RS,SH,WP,WL & June-July \\
\hline & 216 & Euphorbia granulata Forssk. & $874 / \mathrm{MM} / / 2020$ & Ltari booti & $\mathrm{H}$ & DL,FO,GR,HS,MS,SP,SL,WP & August-September \\
\hline & 217 & Euphorbia prolifera Buch.-Ham. ex D.Don & $561 / \mathrm{MM} / / 2020$ & Pholi booti & $\mathrm{H}$ & DL,FO,GL,GR,HS,MS,RS,SP,SL & April-May \\
\hline
\end{tabular}

APPLIED ECOLOGY AND ENVIRONMENTAL RESEARCH 19(5):3343-3376.

http://www.aloki.hu • ISSN 15891623 (Print) • ISSN 17850037 (Online)

DOI: http://dx.doi.org/10.15666/aeer/1905_33433376

( 2021 , ALÖKI Kft., Budapest, Hungary 


\begin{tabular}{|c|c|c|c|c|c|c|c|}
\hline Family & No. & Species & V/No. & Local name & Habit* & Micro-habitats** & Phenology \\
\hline & 218 & Euphorbia serpens Kunth & 779/MM//2020 & Boni booti & $\mathrm{H}$ & DL,FO,GL,GR,HS,MS,RS,SP,SL,SH & August-September \\
\hline & 219 & Ricinus communis $\mathrm{L}$. & 689/MM//2020 & Hernoli & $\mathrm{S}$ & AL,DL,FO,GL,GR,HS,RS,SP,SL,WP & August-September \\
\hline 35. Fagaceae & 220 & Quercus incana Bartram & $617 / \mathrm{MM} / / 2020$ & Shah baloot & $\mathrm{T}$ & AL,FO,GL,HG,RS & August-September \\
\hline \multirow{4}{*}{ 36. Geraniaceae } & 221 & Geranium rotundifolium $\mathrm{L}$. & $722 / \mathrm{MM} / / 2020$ & Bouni booti & $\mathrm{H}$ & AL,FO,GL,GR,RS,SH,WP,WL & March-April \\
\hline & 222 & Geranium lambertii Sweet & $545 / \mathrm{MM} / / 2020$ & Tara booti & $\mathrm{H}$ & FO,GL,RS,SH,WP,WL & March-April \\
\hline & 223 & Geranium pratense L. & $707 / \mathrm{MM} / / 2020$ & Asmani pholi & $\mathrm{H}$ & AL,FO,GR,HS,RS,SH,WP & March-April \\
\hline & 224 & Geranium pusillum $\mathrm{L}$. & $862 / \mathrm{MM} / / 2020$ & Gana booti & $\mathrm{H}$ & FO,GL,GR,HS,RS,SL,SH,WP & August-September \\
\hline 37. Gisekiaceae & 225 & Gisekia pharnaceoides L. & $644 / \mathrm{MM} / / 2020$ & Balu ka sag & $\mathrm{H}$ & AL,FO,GL,GR,RS,SP,SH,WP & July-August \\
\hline \multirow{11}{*}{ 38. Lamiaceae } & 226 & Anisomeles indica (L.) Kuntze & $794 / \mathrm{MM} / / 2020$ & Jamni booti & $\mathrm{H}$ & FO,HS,RS,SH,WP & March-April \\
\hline & 227 & Mentha longifolia $(\mathrm{L}.) \mathrm{L}$. & 698/MM//2020 & Jangli poodina & $\mathrm{H}$ & FO,GL,HS,SL,SH,WL & May-June \\
\hline & 228 & Mentha arvensis $\mathrm{L}$. & 693/MM//2020 & Poodina & $\mathrm{H}$ & AL,GL,HG & March-April \\
\hline & 229 & Mentha pulegium $\mathrm{L}$. & $659 / \mathrm{MM} / / 2020$ & Jamni poodina & $\mathrm{H}$ & AL,FO,GL,HS,RS,SL,SH,WL & March-April \\
\hline & 230 & Mentha royleana Wall. ex Benth. & 631/MM//2020 & Chitta poodina & $\mathrm{H}$ & AL,FO,GL,HS,RS,SL,SH,WL & March-April \\
\hline & 231 & Mentha spicata $\mathrm{L}$. & $503 / \mathrm{MM} / / 2020$ & Podina & $\mathrm{H}$ & FO,GL,HS,SH,WL & March-April \\
\hline & 232 & Ocimum americanum $\mathrm{L}$. & $890 / \mathrm{MM} / / 2020$ & Danadar booti & $\mathrm{H}$ & FO,GR,HS,RS,SL,SH,WP & August-September \\
\hline & 233 & Ocimum basilicum $\mathrm{L}$. & 737/MM//2020 & Niazbo & $\mathrm{S}$ & HG,SH & August-September \\
\hline & 234 & Salvia aegyptiaca $\mathrm{L}$. & 705/MM//2020 & Ksaroo & $\mathrm{H}$ & FO,HS,RS,SP,SL,SH,WP & August-September \\
\hline & 235 & Salvia moorcroftiana Wall. ex Benth. & 530/MM//2020 & Lapra & $\mathrm{H}$ & FO,HS,SL,SH,WP & May-June \\
\hline & 236 & Salvia nubicola Wall. ex Sweet & $841 / \mathrm{MM} / / 2020$ & Hernar & $\mathrm{H}$ & FO,HS,RS,SH,WP,WL & August-September \\
\hline \multirow{13}{*}{ 39. Leguminosae } & 237 & Acacia farnesiana (L.) Willd. & $851 / \mathrm{MM} / / 2020$ & Kabli kikar & $\mathrm{T}$ & DL,FO,HS,RS,WP & August-September \\
\hline & 238 & Acacia nilotica (L.) Delile & 783/MM//2020 & Kikar & $\mathrm{T}$ & DL,FO,HS,RS,SP,WP & August-September \\
\hline & 239 & Acacia catechu (L.f.) Willd. & $514 / \mathrm{MM} / / 2020$ & Wada kiker & $\mathrm{T}$ & DL,FO,HS,RS,WP & July-August \\
\hline & 240 & Acacia modesta Wall. & $827 / \mathrm{MM} / / 2020$ & Pholai kiker & $\mathrm{T}$ & DL,FO,HS,RS,SP,WP & March-April \\
\hline & 241 & Acacia senegal (L.) Willd. & $618 / \mathrm{MM} / / 2020$ & Wlayti kikeri & $\mathrm{T}$ & FO,GL,HG,RS,WP & August-September \\
\hline & 242 & Acacia torta (Roxb.) Craib & $831 / \mathrm{MM} / / 2020$ & Jungli kiker & $\mathrm{S}$ & DL,FO,GL,HS,RS & August-September \\
\hline & 243 & Albizia procera (Roxb.) Benth. & $630 / \mathrm{MM} / / 2020$ & Chita Sharin & $\mathrm{T}$ & AL,DL,GL,HG,RS,SP & August-September \\
\hline & 244 & Albizia lebbeck (L.) Benth. & $597 / \mathrm{MM} / / 2020$ & Shareen & $\mathrm{T}$ & AL,FO,GL,GR,HG,RS,WP & August-September \\
\hline & 245 & Alhagi maurorum Medik. & $610 / \mathrm{MM} / / 2020$ & Kandera & $\mathrm{S}$ & DL,FO,GR,HS,SP & July-August \\
\hline & 246 & Arachis hypogaea $\mathrm{L}$. & $877 / \mathrm{MM} / / 2020$ & Moong phali & $\mathrm{H}$ & AL,DL,GL,SP & August-September \\
\hline & 247 & Astragalus psilocentros Fisch. & $882 / \mathrm{MM} / / 2020$ & Jangli jantri & $\mathrm{H}$ & $\mathrm{HS}$ & August-September \\
\hline & 248 & Bauhinia variegata $\mathrm{L}$ & $685 / \mathrm{MM} / / 2020$ & Kachnar & $\mathrm{T}$ & AL,GL,HG,RS & March-April \\
\hline & 249 & Butea monosperma (Lam.) Taub. & $772 / \mathrm{MM} / / 2020$ & Wlayti sumbal & $\mathrm{T}$ & RS & March-April \\
\hline
\end{tabular}

APPLIED ECOLOGY AND ENVIRONMENTAL RESEARCH 19(5):3343-3376.

http://www.aloki.hu • ISSN 15891623 (Print) • ISSN 17850037 (Online)

DOI: http://dx.doi.org/10.15666/aeer/1905 33433376

○ 2021, ALÖKI Kft., Budapest, Hungary 


\begin{tabular}{|c|c|c|c|c|c|c|c|}
\hline Family & No. & Species & V/No. & Local name & Habit* & Micro-habitats** & Phenology \\
\hline & 250 & Cassia fistula $\mathrm{L}$. & $846 / \mathrm{MM} / / 2020$ & Girdi nalli, Amaltas & $\mathrm{T}$ & AL,GL,HG,RS & March-April \\
\hline & 251 & Cicer arietinum $\mathrm{L}$. & 577/MM//2020 & Choly, chany & $\mathrm{H}$ & AL,DL,SP & February-March \\
\hline & 252 & Dalbergia sissoo DC. & 695/MM//2020 & Tahli & $\mathrm{T}$ & AL,DL,FO,GL,GR,HS,RS,SP,SH,WP,WL & April-May \\
\hline & 253 & Indigofera linifolia (L.f.) Retz. & 714/MM//2020 & Lal dani & $\mathrm{H}$ & DL,FO,GR,HS,RS,SP,SL,SH,WP & March-April \\
\hline & 254 & Indigofera arabica Jaub. \& Spach & 646/MM//2020 & Gulabi pholi & $\mathrm{H}$ & DL,FO,GR,HS,RS,SP,SL,WP & March-April \\
\hline & 255 & Indigofera sessiliflora DC. & 759/MM//2020 & Shareni booti & $\mathrm{H}$ & DL,FO,GR,HS,RS,SL,WP & March-April \\
\hline & 256 & Indigofera tinctoria $\mathrm{L}$. & 849/MM//2020 & Neeli jhari & $\mathrm{S}$ & DL,FO,GR,HS,RS,SL,WP & November-December \\
\hline & 257 & Indigofera trita L.f. & 680/MM//2020 & Lal pholi & $\mathrm{H}$ & AL,FO,GL,RS,SH,WP,WL & February-March \\
\hline & 258 & Lathyrus aphaca $\mathrm{L}$. & 844/MM//2020 & Jangli mattar & $\mathrm{H}$ & AL,FO,GL,RS,SH,WP,WL & September-October \\
\hline & 259 & Lathyrus sativus $\mathrm{L}$. & $572 / \mathrm{MM} / / 2020$ & Jangli mattri & $\mathrm{H}$ & AL,FO,GL,HS,RS,WP,WL & March-April \\
\hline & 260 & Lathyrus pratensis $\mathrm{L}$. & $818 / \mathrm{MM} / / 2020$ & Peeli vail & $\mathrm{H}$ & AL,FO,GL,HS,RS,WP,WL & March-April \\
\hline & 261 & Lens culinaris Medik. & $516 / \mathrm{MM} / / 2020$ & Dal masoor & $\mathrm{H}$ & AL,GL,HG & February-March \\
\hline & 262 & Leucaena leucocephala (Lam.) de Wit & $550 / \mathrm{MM} / / 2020$ & Desi shareen & $\mathrm{T}$ & AL,GL,GR,HS,HG,RS,WP & March-April \\
\hline & 263 & Medicago sativa $\mathrm{L}$. & $662 / \mathrm{MM} / / 2020$ & Lucen, Losan & $\mathrm{H}$ & AL,GL & June-July \\
\hline & 264 & Melilotus indicus (L.) All. & 754/MM//2020 & Senji & $\mathrm{H}$ & AL,GL,GR,RS,SH,WP,WL & March-April \\
\hline & 265 & Melilotus officinalis (L.) Pall. & 600/MM//2020 & Chitti Sinje & $\mathrm{H}$ & AL,GL,GR,RS,SH,WP,WL & March-April \\
\hline & 266 & Melilotus messanensis (L.) All. & 790/MM//2020 & Patrro & $\mathrm{H}$ & AL,GL,RS,WP,WL & March-April \\
\hline & 267 & Parkinsonia aculeata $\mathrm{L}$. & 667/MM//2020 & Angrezi kikar & $\mathrm{T}$ & DL,FO,GR,HS,RS,SP,WP & August-September \\
\hline & 268 & Pisum sativum $\mathrm{L}$. & 711/MM//2020 & Mattar & $\mathrm{H}$ & $\mathrm{AL}, \mathrm{GL}$ & September-October \\
\hline & 269 & Pongamia pinnata $(\mathrm{L}$.) Pierre & 592/MM//2020 & Sukh chain & $\mathrm{T}$ & AL,GL,HG,RS & August-September \\
\hline & 270 & Prosopis cineraria $(\mathrm{L}$.) Druce & 745/MM//2020 & Jand & $\mathrm{T}$ & DL,FO,GR,HS,RS,SP,SL,WP & August-September \\
\hline & 271 & Prosopis glandulosa Torr. & 886/MM//2020 & Wlayti kikar & $\mathrm{T}$ & AL,DL,FO,GR,HS,RS,SP,SL & August-September \\
\hline & 272 & Prosopis juliflora (Sw.) DC. & $547 / \mathrm{MM} / / 2020$ & Phari kikar & $\mathrm{T}$ & AL,FO,GR,HS,RS,WP & August-September \\
\hline & 273 & Rhynchosia capitata (Roth) DC & 686/MM//2020 & Rawan & $\mathrm{H}$ & AL,GL,HG & March-April \\
\hline & 274 & Rhynchosia minima (L.) DC. & $855 / \mathrm{MM} / / 2020$ & Jangli Rawan & $\mathrm{H}$ & $\mathrm{AL}, \mathrm{FO}, \mathrm{HS}, \mathrm{HG}, \mathrm{RS}, \mathrm{WP}, \mathrm{WL}$ & March-April \\
\hline & 275 & Senna occidentalis (L.) Link & $576 / \mathrm{MM} / / 2020$ & Jangli arwan & $\mathrm{H}$ & $\mathrm{AL}, \mathrm{FO}, \mathrm{HS}, \mathrm{HG}, \mathrm{RS}, \mathrm{WP}, \mathrm{WL}$ & March-April \\
\hline & 276 & Senna tora $(\mathrm{L}$.$) Roxb.$ & 766/MM//2020 & Jantar & $\mathrm{H}$ & $\mathrm{AL}, \mathrm{GL}$ & March-April \\
\hline & 277 & Sesbania sesban (L.) Merr. & 581/MM//2020 & Wlayti shareen & $\mathrm{T}$ & FO,HS,HG,RS,WP & August-September \\
\hline & 278 & Sesbania concolor J.B.Gillett & 620/MM//2020 & Jungli shareen & $\mathrm{S}$ & FO,HS,HG,RS & August-September \\
\hline & 279 & Sesbania grandiflora (L.) Pers. & 607/MM//2020 & Majandri & $\mathrm{T}$ & FO,HS,HG,RS & November-December \\
\hline & 280 & Tamarindus indica $\mathrm{L}$. & 798/MM//2020 & Imli & $\mathrm{T}$ & AL,GL,HG,RS & December-January \\
\hline & 281 & Trifolium resupinatum $\mathrm{L}$. & 788/MM//2020 & Barsan & $\mathrm{H}$ & AL,GL & March-April \\
\hline
\end{tabular}

APPLIED ECOLOGY AND ENVIRONMENTAL RESEARCH 19(5):3343-3376.

http://www.aloki.hu • ISSN 15891623 (Print) • ISSN 17850037 (Online)

DOI: http://dx.doi.org/10.15666/aeer/1905 33433376

○ 2021, ALÖKI Kft., Budapest, Hungary 


\begin{tabular}{|c|c|c|c|c|c|c|c|}
\hline Family & No. & Species & V/No. & Local name & Habit* & Micro-habitats** & Phenology \\
\hline & 282 & Trifolium alexandrinum $\mathrm{L}$. & 717/MM//2020 & Chita Shatala & $\mathrm{H}$ & $\mathrm{AL}, \mathrm{GL}$ & March-April \\
\hline & 283 & Trifolium pratense $\mathrm{L}$. & 556/MM//2020 & Gulabi Shatala & $\mathrm{H}$ & $\mathrm{AL}, \mathrm{GL}$ & March-April \\
\hline & 284 & Trifolium repens $\mathrm{L}$. & $579 / \mathrm{MM} / / 2020$ & Shatala & $\mathrm{H}$ & $\mathrm{AL}, \mathrm{GL}$ & February-March \\
\hline & 285 & Trigonella anguina Delile & $568 / \mathrm{MM} / / 2020$ & Jangli meethre & $\mathrm{H}$ & AL,DL,FO,GL,GR,HS,RS,SH,WP,WL & March-April \\
\hline & 286 & Trigonella corniculata Sibth. \& Sm. & $615 / \mathrm{MM} / / 2020$ & Meethre & $\mathrm{H}$ & AL,HG & March-April \\
\hline & 287 & Trigonella foenum-graecum $\mathrm{L}$. & 901/MM//2020 & Methra & $\mathrm{H}$ & $\mathrm{AL}, \mathrm{HG}$ & March-April \\
\hline & 288 & Vicia sativa $\mathrm{L}$ & 767/MM//2020 & Jangli Rewari & $\mathrm{H}$ & $\mathrm{AL}, \mathrm{FO}, \mathrm{GL}, \mathrm{HS}, \mathrm{SL}, \mathrm{SH}, \mathrm{WP}, \mathrm{WL}$ & March-April \\
\hline & 289 & Vicia bakeri Ali & $549 / \mathrm{MM} / / 2020$ & Daturi & $\mathrm{H}$ & AL,FO,GL,HS,RS,SH,WP,WL & August-September \\
\hline & 290 & Vicia faba $\mathrm{L}$. & 725/MM//2020 & Lobia & $\mathrm{H}$ & $\mathrm{AL}, \mathrm{GL}, \mathrm{HG}$ & December-January \\
\hline & 291 & Vigna mungo (L.) Hepper & 777/MM//2020 & Mung dal & $\mathrm{H}$ & AL,GL,HG & February-March \\
\hline & 292 & Vigna trilobata (L.) Verdc. & $832 / \mathrm{MM} / / 2020$ & Rawan dal & $\mathrm{H}$ & AL,GL,HG & February-March \\
\hline & 293 & Vigna unguiculata (L.) Walp. & $560 / \mathrm{MM} / / 2020$ & Lobia & $\mathrm{H}$ & AL,HG & February-March \\
\hline 40. Linaceae & 294 & Linum usitatissimum $\mathrm{L}$. & $857 / \mathrm{MM} / / 2020$ & Alsi & $\mathrm{H}$ & AL,HG & June-July \\
\hline \multirow{4}{*}{ 41. Lythraceae } & 295 & Ammannia baccifera $\mathrm{L}$. & 613/MM//2020 & Ratta krond & $\mathrm{H}$ & AL,DL,FO,GL,HS,RS,SL,WP,WL & August-September \\
\hline & 296 & Ammannia auriculata Willd. & $536 / \mathrm{MM} / / 2020$ & Kandi booti & $\mathrm{H}$ & AL,DL,FO,GL,GR,HS,RS,SL,SH,WP & August-September \\
\hline & 297 & Ammannia verticillata (Ard.) Lam. & 902/MM//2020 & Nevi kandi & $\mathrm{H}$ & AL,DL,FO,GL,GR,HS,RS,WP & August-September \\
\hline & 298 & Lawsonia inermis $\mathrm{L}$. & 833/MM//2020 & Mehndi & $\mathrm{S}$ & AL,GL,HG & March-April \\
\hline \multirow{14}{*}{ 42. Malvaceae } & 299 & Abelmoschus esculentus L. Moench & $567 / \mathrm{MM} / / 2020$ & Bhindi & $\mathrm{H}$ & AL,HG & June-July \\
\hline & 300 & Abutilon indicum (L.) Sweet & 588/MM//2020 & Peela crown & $\mathrm{H}$ & FO,GR,HS,RS,SL,SH,WP & March-April \\
\hline & 301 & Abutilon theophrasti Medik. & 543/MM//2020 & Janlgi Peela crown & $\mathrm{H}$ & FO,GR,HS,RS,SL,WP & March-April \\
\hline & 302 & Abutilon grandifolium (Willd.) Sweet & 765/MM//2020 & Gidar booti & $\mathrm{S}$ & FO,GR,HS,RS,SL,WP & July-August \\
\hline & 303 & Abutilon hirtum (Lam.) Sweet & $800 / \mathrm{MM} / / 2020$ & Peeli booti & $\mathrm{H}$ & FO,RS,SL,WP & March-April \\
\hline & 304 & Bombax ceiba $\mathrm{L}$. & 786/MM//2020 & Simbal & $\mathrm{T}$ & AL,GL,GR,RS & February-March \\
\hline & 305 & Corchorus depressus (L.) Stocks & $591 / \mathrm{MM} / / 2020$ & Bahu-phali & $\mathrm{H}$ & DL,GR,HS,MS,SP,SL & March-April \\
\hline & 306 & Grewia asiatica $\mathrm{L}$. & 721/MM//2020 & Falsa & $\mathrm{S}$ & AL,GL,HG,RS & February-March \\
\hline & 307 & Malva neglecta Wallr. & $665 / \mathrm{MM} / / 2020$ & Sitara Sunchal & $\mathrm{H}$ & AL,DL,FO,GL,GR,RS,SH,WP,WL & March-April \\
\hline & 308 & Malva parviflora $\mathrm{L}$. & $510 / \mathrm{MM} / / 2020$ & Sunchal & $\mathrm{H}$ & AL,DL,FO,GL,GR,RS,SH,WP,WL & March-April \\
\hline & 309 & Malva sylvestris $\mathrm{L}$. & $564 / \mathrm{MM} / / 2020$ & Jamni phool & $\mathrm{H}$ & HG,RS,SH & April-May \\
\hline & 310 & Malva verticillata $\mathrm{L}$. & $885 / \mathrm{MM} / / 2020$ & Kandi Sunchal & $\mathrm{H}$ & AL,GL,GR,RS,SH,WP,WL & March-April \\
\hline & 311 & Malvastrum coromandelianum (L.) Garcke & $642 / \mathrm{MM} / / 2020$ & Khati booti, Peeli booti & $\mathrm{H}$ & DL,FO,GL,GR,HS,MS,RS,SL,SH,WP & October-November \\
\hline & 312 & Sida spinosa $\mathrm{L}$. & 719/MM//2020 & Jungle maithi & $\mathrm{H}$ & FO,GL,GR,HS,MS,RS,SH,WP & March-April \\
\hline 43. Martyniaceae & 313 & Martynia аппиа $\mathrm{L}$. & $575 / \mathrm{MM} / / 2020$ & Gulabi kona & $\mathrm{H}$ & FO,GL,GR,HS,MS,RS,SL,SH,WP,WL & March-April \\
\hline
\end{tabular}

APPLIED ECOLOGY AND ENVIRONMENTAL RESEARCH 19(5):3343-3376.

http://www.aloki.hu • ISSN 15891623 (Print) • ISSN 17850037 (Online)

DOI: http://dx.doi.org/10.15666/aeer/1905_33433376

○ 2021, ALÖKI Kft., Budapest, Hungary 


\begin{tabular}{|c|c|c|c|c|c|c|c|}
\hline Family & No. & Species & V/No. & Local name & Habit* & Micro-habitats** & Phenology \\
\hline \multirow{2}{*}{ 44. Meliaceae } & 314 & Azadirachta indica A.Juss. & 633/MM//2020 & Neem & $\mathrm{T}$ & AL,GL,HG,RS & July-August \\
\hline & 315 & Melia azedarach $\mathrm{L}$. & $864 / \mathrm{MM} / / 2020$ & Dharaik & $\mathrm{T}$ & AL,GL,HG,RS & August-September \\
\hline 45. Menispermaceae & 316 & Tinospora sinensis (Lour.) Merr. & $639 / \mathrm{MM} / / 2020$ & Glow & $\mathrm{S}$ & AL,GL,HG & April-May \\
\hline \multirow{8}{*}{ 46. Moraceae } & 317 & Broussonetia papyrifera (L.) L'Hér. ex Vent. & $817 / \mathrm{MM} / / 2020$ & Gul toot & $\mathrm{T}$ & HG,RS & March-April \\
\hline & 318 & Ficus benghalensis $\mathrm{L}$. & 593/MM//2020 & Desi bohar & $\mathrm{T}$ & AL,GL,HG,RS & March-April \\
\hline & 319 & Ficus carica $\mathrm{L}$. & 749/MM//2020 & Anjeer & $\mathrm{T}$ & AL,GL,HG,RS & May-June \\
\hline & 320 & Ficus religiosa $\mathrm{L}$. & 791/MM//2020 & Peepal & $\mathrm{T}$ & AL,GL,HG,RS & August-September \\
\hline & 321 & Ficus palmata Forssk. & $879 / \mathrm{MM} / / 2020$ & Desi Anjeer & $\mathrm{T}$ & AL,GL,HG,RS & May-June \\
\hline & 322 & Ficus sarmentosa Buch.-Ham. ex Sm. & $521 / \mathrm{MM} / / 2020$ & Wlayti bohar & $\mathrm{T}$ & AL,GL,RS & August-September \\
\hline & 323 & Morus alba $\mathrm{L}$. & $866 / \mathrm{MM} / / 2020$ & Safaid toot & $\mathrm{T}$ & AL,GL,HG,RS & March-April \\
\hline & 324 & Morus nigra $\mathrm{L}$. & $625 / \mathrm{MM} / / 2020$ & Kala toot & $\mathrm{T}$ & AL,GL,HG,RS & March-April \\
\hline 47. Moringaceae & 325 & Moringa oleifera Lam. & 700/MM//2020 & Sohanjana & $\mathrm{T}$ & AL,GL,HG,RS & February-March \\
\hline 48. Musaceae & 326 & Musa $\times$ paradisiaca $\mathrm{L}$. & 645/MM//2020 & Keela & $\mathrm{H}$ & AL,GL,HG,WL & March-April \\
\hline \multirow{4}{*}{ 49. Myrtaceae } & 327 & Callistemon lanceolatus $(\mathrm{Sm}$.$) Sweet$ & $643 / \mathrm{MM} / / 2020$ & Bottle bursh & $\mathrm{T}$ & HG,RS & March-April \\
\hline & 328 & Eucalyptus globulus Labill. & 554/MM//2020 & Saifeda & $\mathrm{T}$ & AL,GL,GR,RS,WL & August-September \\
\hline & 329 & Psidium guajava $\mathrm{L}$. & $859 / \mathrm{MM} / / 2020$ & Amrood & $\mathrm{S}$ & AL,GL,HG & January-February \\
\hline & 330 & Syzygium cumini (L.) Skeels & $808 / \mathrm{MM} / / 2020$ & Kala jaman & $\mathrm{T}$ & AL,HG,RS & August-September \\
\hline 50. Nitrariaceae & 331 & Peganum harmala $\mathrm{L}$. & 701/MM//2020 & Harmal booti & $\mathrm{H}$ & DL,FO,GR,HS,MS,RS,SP & March-April \\
\hline \multirow{6}{*}{ 51. Nyctaginaceae } & 332 & Boerhavia diffusa $\mathrm{L}$. & $504 / \mathrm{MM} / / 2020$ & Nevi booti & $\mathrm{H}$ & AL,FO,GL,HS,RS,SL,SH,WP & July-August \\
\hline & 333 & Boerhavia procumbens Banks ex Roxb. & 649/MM//2020 & Itsit & $\mathrm{H}$ & FO,GL,HS,RS,WP & June-July \\
\hline & 334 & Boerhavia repens $\mathrm{L}$. & $816 / \mathrm{MM} / / 2020$ & Looni booti & $\mathrm{H}$ & AL,FO,GL,GR,HS,RS,SH,WP & August-September \\
\hline & 335 & Bougainvillea glabra Choisy & $520 / \mathrm{MM} / / 2020$ & Rangli bail & $\mathrm{S}$ & HG,RS & August-September \\
\hline & 336 & Bougainvillea spectabilis Willd. & 723/MM//2020 & Bugal bail & $\mathrm{S}$ & HG,RS & August-September \\
\hline & 337 & Mirabilis jalapa L. & $526 / \mathrm{MM} / / 2020$ & Gul-e-Asar & $\mathrm{H}$ & HG,RS & August-September \\
\hline \multirow{3}{*}{ 52. Oleaceae } & 338 & Jasminum grandiflorum $\mathrm{L}$. & $594 / \mathrm{MM} / / 2020$ & Chambeli & $\mathrm{S}$ & AL,HG & July-September \\
\hline & 339 & Jasminum sambac (L.) Aiton & $641 / \mathrm{MM} / / 2020$ & Motiya & $\mathrm{S}$ & AL,HG & July-September \\
\hline & 340 & Olea ferruginea Wall. ex Aitch. & 746/MM//2020 & Kao & $\mathrm{S}$ & $\mathrm{AL}$ & August-September \\
\hline 53. Oxalidaceae & 341 & Oxalis corniculata $\mathrm{L}$. & 732/MM//2020 & Peeli booti, Choti lonak & $\mathrm{H}$ & AL,FO,GL,GR,HS,RS,SH,WP,WL & February-March \\
\hline \multirow{2}{*}{ 54. Papaveraceae } & 342 & Fumaria indica (Hausskn.) Pugsley & $537 / \mathrm{MM} / / 2020$ & Papra & $\mathrm{H}$ & AL,GL,HS,RS,SH,WP & March-April \\
\hline & 343 & Fumaria vaillantii Loisel. & $899 / \mathrm{MM} / / 2020$ & Shatra papra & $\mathrm{H}$ & AL,GL,HS,RS,SH,WP & March-April \\
\hline 55. Pedaliaceae & 344 & Sesamum indicum $\mathrm{L}$. & $835 / \mathrm{MM} / / 2020$ & Till & $\mathrm{H}$ & $\mathrm{AL}$ & March-April \\
\hline 56. Phrymaceae & 345 & Mazus pumilus (Burm.f.) Steenis & 691/MM//2020 & Chita phol & $\mathrm{H}$ & FO,GR,HS,RS,SH,WL & March-April \\
\hline
\end{tabular}

APPLIED ECOLOGY AND ENVIRONMENTAL RESEARCH 19(5):3343-3376.

http://www.aloki.hu • ISSN 15891623 (Print) • ISSN 17850037 (Online)

DOI: http://dx.doi.org/10.15666/aeer/1905_33433376

( 2021 , ALÖKI Kft., Budapest, Hungary 


\begin{tabular}{|c|c|c|c|c|c|c|c|}
\hline Family & No. & Species & V/No. & Local name & Habit* & Micro-habitats** & Phenology \\
\hline 57. Plantaginaceae & 346 & Veronica anagallis-aquatica $\mathrm{L}$. & $834 / \mathrm{MM} / / 2020$ & Hazar booti & $\mathrm{H}$ & AL,FO,GL,HS,RS,SH,WP & March-April \\
\hline \multirow{5}{*}{ 58. Polygonaceae } & 347 & Persicaria glabra (Willd.) M.Gómez & 523/MM//2020 & Hazar dani & $\mathrm{H}$ & AL,FO,GL,HS,RS,SP,SH,WP & September-October \\
\hline & 348 & Polygonum plebeium R.Br. & $531 / \mathrm{MM} / / 2020$ & Droonk, Gorakh pan & $\mathrm{H}$ & AL,FO,GL,GR,HS,MS,RS,SL,SH,WP,WL & March-April \\
\hline & 349 & Rumex crispus $\mathrm{L}$. & $650 / \mathrm{MM} / / 2020$ & Lonak & $\mathrm{H}$ & AL,FO,GL,HS,RS,SL,SH,WP,WL & March-April \\
\hline & 350 & Rumex dentatus $\mathrm{L}$. & $812 / \mathrm{MM} / / 2020$ & Khatkal & $\mathrm{H}$ & AL,FO,GL,HS,RS,SL,SH,WP,WL & March-April \\
\hline & 351 & Rumex patientia $\mathrm{L}$. & $860 / \mathrm{MM} / / 2020$ & Khatkal & $\mathrm{H}$ & $\mathrm{AL}, \mathrm{FO}, \mathrm{GL}, \mathrm{GR}, \mathrm{HS}, \mathrm{MS}, \mathrm{RS}, \mathrm{SH}, \mathrm{WP}, \mathrm{WL}$ & March-April \\
\hline \multirow{4}{*}{ 59. Portulacaceae } & 352 & Portulaca grandiflora Hook. & 763/MM//2020 & Kulfa & $\mathrm{H}$ & $\mathrm{DL}, \mathrm{FO}, \mathrm{GL}, \mathrm{GR}, \mathrm{HS}, \mathrm{RS}, \mathrm{SP}, \mathrm{SL}$ & August-September \\
\hline & 353 & Portulaca oleracea $\mathrm{L}$. & $865 / \mathrm{MM} / / 2020$ & Kulfa lonak & $\mathrm{H}$ & FO,GL,HS,RS,SH,WP,WL & August-September \\
\hline & 354 & Portulaca pilosa $\mathrm{L}$. & $829 / \mathrm{MM} / / 2020$ & Lorni booti & $\mathrm{H}$ & FO,GL,HS,MS,RS,SH & August-September \\
\hline & 355 & Portulaca quadrifida $\mathrm{L}$. & 753/MM//2020 & Lornak booti & $\mathrm{H}$ & FO,GL,GR,HS,MS,RS,SL,SH,WP & August-September \\
\hline 60. Primulaceae & 356 & Anagallis arvensis $\mathrm{L}$. & 900/MM//2020 & Neeli booti, Billi booti. & $\mathrm{H}$ & AL,FO,GL,GR,HS,MS,RS,SH,WP & March-April \\
\hline \multirow{6}{*}{ 61. Ranunculaceae } & 357 & Nigella sativa $\mathrm{L}$. & 740/MM//2020 & Kalwanji & $\mathrm{H}$ & AL,HG & March-April \\
\hline & 358 & Ranunculus muricatus $\mathrm{L}$. & 773/MM//2020 & Chambel booti & $\mathrm{H}$ & FO,GL,SH,WP & March-April \\
\hline & 359 & Ranunculus sceleratus $\mathrm{L}$. & $571 / \mathrm{MM} / / 2020$ & Jal Dhania & $\mathrm{H}$ & FO,GL,GR,HS,RS,SL,SH & February-March \\
\hline & 360 & Ranunculus arvensis $\mathrm{L}$. & 739/MM//2020 & Peela phola & $\mathrm{H}$ & DL,GL,HS,SP,SH,WP & March-April \\
\hline & 361 & Ranunculus natans C.A.Mey. & 697/MM//2020 & Peela tara & $\mathrm{H}$ & FO,GL,GR,HS,SP,SH & August-September \\
\hline & 362 & Ranunculus repens $\mathrm{L}$. & 738/MM//2020 & Peela Gullab & $\mathrm{H}$ & GL,GR,HS,RS,SH,WP & June-July \\
\hline \multirow{2}{*}{ 62. Rhamnaceae } & 363 & Ziziphus jujuba Mill. & 726/MM//2020 & Bairi & $\mathrm{T}$ & DL,FO,GL,GR,HS,HG,RS,SP & August-September \\
\hline & 364 & Ziziphus nummularia (Burm.f.) Wight \& Arn. & 612/MM//2020 & Jangli bairi & $\mathrm{T}$ & FO,GL,HS,RS,SP & August-September \\
\hline 63. Rosaceae & 365 & Rosa indica $\mathrm{L}$. & $814 / \mathrm{MM} / / 2020$ & Gulaab & $\mathrm{S}$ & HG,RS & March-April \\
\hline 64. Rubiaceae & 366 & Galium aparine $\mathrm{L}$. & 589/MM//2020 & Wanwair booti & $\mathrm{H}$ & AL,FO,GL,GR,HS,RS,SL,SH,WP & June-July \\
\hline \multirow{3}{*}{ 65. Rutaceae } & 367 & Citrus limon (L.) Osbeck & $869 / \mathrm{MM} / / 2020$ & Nimboo & $\mathrm{S}$ & $\mathrm{AL}, \mathrm{HG}$ & March-April \\
\hline & 368 & Citrus reticulata Blanco & 836/MM//2020 & Kino malta & $\mathrm{S}$ & $\mathrm{AL}, \mathrm{HG}$ & September-October \\
\hline & 369 & Citrus sinensis (L.) Osbeck & 743/MM//2020 & Musmi malta & $\mathrm{S}$ & AL,HG & September-October \\
\hline \multirow{2}{*}{ 66. Salicaceae } & 370 & Populus alba $\mathrm{L}$. & 778/MM//2020 & Sufaid Poplar & $\mathrm{T}$ & AL,HG & February-March \\
\hline & 371 & Salix alba $\mathrm{L}$. & 599/MM//2020 & Desi bohoer & $\mathrm{T}$ & $\mathrm{AL}, \mathrm{GL}, \mathrm{GR}, \mathrm{HG}, \mathrm{RS}$ & February-April \\
\hline \multirow{2}{*}{ 67. Salvadoraceae } & 372 & Salvadora oleoides Decne. & $690 / \mathrm{MM} / / 2020$ & Jall, Van & $\mathrm{T}$ & DL,FO,GR,HS,SP,WP & August-September \\
\hline & 373 & Salvadora persica $\mathrm{L}$. & 747/MM//2020 & Pelo & $\mathrm{S}$ & DL,GR,RS,SP,SL,WP & August-September \\
\hline 68. Sapindaceae & 374 & Dodonaea viscosa (L.) Jacq. & 768/MM//2020 & Sanatha & $\mathrm{S}$ & FO,GR,HS,MS,RS,SL,SH,WP & March-April \\
\hline 69. Scrophulariaceae & 375 & Verbascum thapsus $\mathrm{L}$. & 891/MM//2020 & Gidhar tambaku & $\mathrm{H}$ & FO,GR,HS,SP,SH & March-April \\
\hline \multirow{2}{*}{ 70. Solanaceae } & 376 & Capsicum аппиит $\mathrm{L}$. & 742/MM//2020 & Shimla mirch & $\mathrm{H}$ & AL,GL,HG & June-July \\
\hline & 377 & Cestrum nocturnum $\mathrm{L}$. & $838 / \mathrm{MM} / / 2020$ & Rat ki rani & $\mathrm{S}$ & HG,RS & March-April \\
\hline
\end{tabular}

APPLIED ECOLOGY AND ENVIRONMENTAL RESEARCH 19(5):3343-3376.

http://www.aloki.hu • ISSN 15891623 (Print) • ISSN 17850037 (Online)

DOI: http://dx.doi.org/10.15666/aeer/1905_33433376

○ 2021, ALÖKI Kft., Budapest, Hungary 


\begin{tabular}{|c|c|c|c|c|c|c|c|}
\hline Family & No. & Species & V/No. & Local name & Habit* & Micro-habitats** & Phenology \\
\hline & 378 & Datura innoxia Mill. & 519/MM//2020 & Siah dhatoora & $\mathrm{S}$ & FO,GL,GR,HS,MS,RS,SH,WP & August-September \\
\hline & 379 & Datura metel L. & $628 / \mathrm{MM} / / 2020$ & Datura & S & FO,GL,GR,HS,MS,RS,SP,SL,SH,WP,WL & June-July \\
\hline & 380 & Datura stramonium L. & $627 / \mathrm{MM} / / 2020$ & Jangli dhatoora & $S$ & FO,GL,GR,HS,MS,RS,SP,SL,SH,WP,WL & June-July \\
\hline & 381 & Hyoscyamus niger $\mathrm{L}$. & 683/MM//2020 & Khoob kalan & $\mathrm{H}$ & GL,HS,RS,SH,WP & March-April \\
\hline & 382 & Nicotiana tabacum $\mathrm{L}$. & 679/MM//2020 & Tambaku & $\mathrm{H}$ & AL,GL,HG & July-September \\
\hline & 383 & Physalis alkekengi $\mathrm{L}$. & 769/MM//2020 & Lal cherry & $\mathrm{H}$ & FO,GL,HS,SH & June-July \\
\hline & 384 & Physalis minima $\mathrm{L}$. & 733/MM//2020 & Jangli rasbari & $\mathrm{H}$ & FO,GL,HS,SL,SH & August-October \\
\hline & 385 & Physalis divaricata D. Don & $569 / \mathrm{MM} / / 2020$ & Jungli berry & $\mathrm{H}$ & FO,GL,HS,SL,SH,WP & August-September \\
\hline & 386 & Physalis peruviana $\mathrm{L}$. & $502 / \mathrm{MM} / / 2020$ & Jungli berry & $\mathrm{H}$ & FO,GL,GR,HS,SL,SH & August-September \\
\hline & 387 & Solanum americanum Mill. & 636/MM//2020 & Kainch Mainch, Makao & $\mathrm{H}$ & AL,FO,GL,GR,HS,RS,SH,WP & June-July \\
\hline & 388 & Solanum incanum $\mathrm{L}$. & 727/MM//2020 & \begin{tabular}{|c|} 
Jangli baingan, \\
Mahokari
\end{tabular} & S & FO,GL,HS,SH,WP & June-July \\
\hline & 389 & Solanum melongena $\mathrm{L}$. & $681 / \mathrm{MM} / / 2020$ & Baingan & $\mathrm{H}$ & $\mathrm{AL}, \mathrm{HG}$ & June-July \\
\hline & 390 & Solanum nigrum $\mathrm{L}$. & 603/MM//2020 & Kanch Manch, Makao & $\mathrm{H}$ & AL,DL,FO,GL,GR,HS,RS,SP,SL,SH,WP,WL & March-April \\
\hline & 391 & Solanum surattense Burm. f. & 758/MM//2020 & Choti Kandiari & $\mathrm{H}$ & DL,FO,GR,HS,MS,RS,SP,SL & October-November \\
\hline & 392 & Solanum tuberosum $\mathrm{L}$. & 596/MM//2020 & Allo & $\mathrm{H}$ & AL,HG & January-February \\
\hline & 393 & Withania somnifera (L.) Dunal & $555 / \mathrm{MM} / / 2020$ & $\begin{array}{l}\text { Aksn, Jangli panair, } \\
\text { Akeri }\end{array}$ & $\mathrm{H}$ & DL,FO,GL,GR,HS,RS,SP,SL,SH,WP & March-April \\
\hline & 394 & Withania coagulans (Stocks) Dunal & $741 / \mathrm{MM} / / 2020$ & Jangly chana & $S$ & $\mathrm{DL}, \mathrm{FO}, \mathrm{GL}, \mathrm{SP}, \mathrm{SH}$ & March-April \\
\hline \multirow{2}{*}{ 71. Tamaricaceae } & 395 & Tamarix aphylla (L.) H.Karst. & 868/MM//2020 & Khagal & $\mathrm{T}$ & DL,FO,GL,RS,WP & March-April \\
\hline & 396 & Tamarix dioica Roxb. ex Roth & 676/MM//2020 & Khagal, Rukh & S & DL,FO,GL,GR,RS,SP,SL,WP & August-September \\
\hline \multirow{4}{*}{ 72. Verbenaceae } & 397 & Lantana camara $\mathrm{L}$. & 708/MM//2020 & Rangli jhari & S & FO,GL,HS,RS & August-September \\
\hline & 398 & Lantana indica Roxb. & 797/MM//2020 & Chitti rangli & $\mathrm{S}$ & FO,GL,HS,RS & August-September \\
\hline & 399 & Phyla nodiflora (L.) Greene & 595/MM//2020 & Bukand booti & $\mathrm{H}$ & FO,GL,MS,SH,WP,WL & August-September \\
\hline & 400 & Verbena officinalis L. & $752 / \mathrm{MM} / / 2020$ & Chandni, Sindhi podina & $\mathrm{H}$ & FO,GL,HS,MS,SL,SH,WL & August-September \\
\hline 73. Violaceae & 401 & Viola pilosa Blume & 647/MM//2020 & \begin{tabular}{|c|} 
Lillio \\
\end{tabular} & $\mathrm{H}$ & FO,GL,HS,SH,WL & April-May \\
\hline 74. Vitaceae & 402 & Vitis vinifera Linn. & $655 / \mathrm{MM} / / 2020$ & Angoor & $\mathrm{S}$ & $\mathrm{AL}, \mathrm{HG}$ & June-July \\
\hline \multirow{2}{*}{ 75. Zygophyllaceae } & 403 & Fagonia indica Burm.f. & $842 / \mathrm{MM} / / 2020$ & Jawanh booti & $\mathrm{S}$ & DL,FO,GR,HS,RS,SP,SL & July-August \\
\hline & 404 & Tribulus terrestris $\mathrm{L}$. & 539/MM//2020 & Bhakhra & $\mathrm{H}$ & DL,FO,GL,GR,HS,MS,RS,SP,SL,SH,WP & August-September \\
\hline
\end{tabular}

*; H: Herbs; S: Shrubs; T: Tree; G: Grass; **; AL: Arable Land; DL: Dry Land; FO: Forest; GL: Grassland; GR: Graveyard; HS: Hilly Slopes; HG: Home Gardens; MS: Mountain Summits; RS: Roadside; SP: Sandy Places; SL: Scrubland; SH: Shady Places; WP: Waste Places; WL: Wet Land 